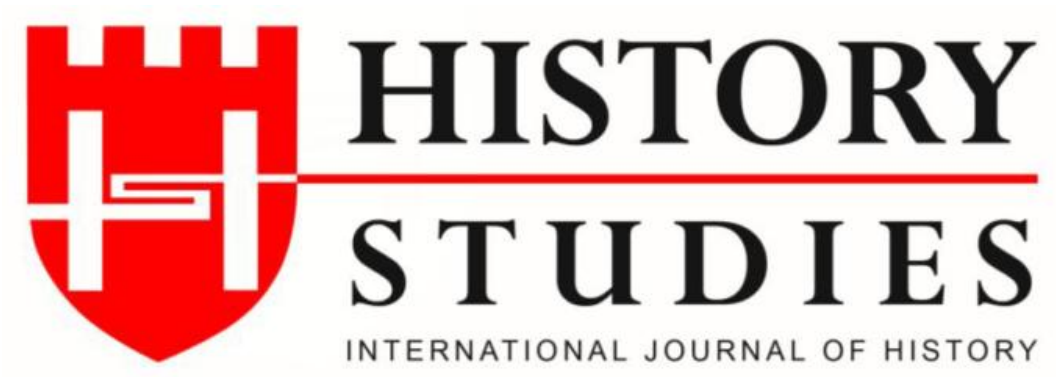

ISSN: 13094173 (Online) 1309 - 4688 (Print)

Volume 12 Issue 5, October 2020

DOI Number: 10.9737/hist.2020.922

Araştırma Makalesi

Makalenin Geliş Tarihi: 10.07.2020 Kabul Tarihi: 01.09.2020

Atıf Künyesi: Efecan Anaz, "Finike-Fenike Eşleşmesinin Kökenleri ve "Finike” İsminin Günümüze Ulaşması", History Studies, 12/5, Ekim 2020, s. 2319-2346.

\title{
Finike-Fenike Eşleşmesinin Kökenleri ve "Finike” İsminin Günümüze Ulaşması
}

The Roots of the Setting Finike up against Phoenicia, and the Reaching of Name "Finike" the Present Day

\author{
Efecan Anaz \\ ORCID No: 0000-0001-8810-8347 \\ Ankara Üniversitesi
}

$\ddot{O} \mathbf{z}$

$\mathrm{Bu}$ çalışmanın amacı, günümüzde Antalya Körfezi’nin güneybatısında yer alan Finike yerleşiminin, Antik Dönem'deki Fenike bölgesiyle eşleştirilmesinin kökenlerini ve Finike isminin günümüze kadar nasıl geldiğini ortaya çıkartmaktır. Bu doğrultuda bölgeyle ilişkilendirilebilecek yazılı, arkeolojik, antropolojik veriler; arşiv belgeleri, resmi yayınlar, seyahatnameler, araştırma eserler, bilimsel makaleler, tezler ve internet kaynaklarından yararlanılmış ve buradaki bilgiler karşılaştırılmalı ve sistematik olarak değerlendirilmiştir. Araştırmada, Fenike (Phoinike) kelimesinin varyasyonlarına sahip çeşitli yerleşimlerin bölgede farklı farklı dönemler boyunca görüldüğü; ancak bunların niteliği, boyutu ve lokalizasyonunun tam olarak bilinemediği ortaya çıkmıştır. Ayrıca Bizans Dönemi’nden günümüze kadar olan süreçte kentten ve bölgeden Fenike olarak bahsedildiği, kentin içindeki mevkilere ilişkin isimlendirmelerde ise dönem dönem farklılıklar bulunduğu tespit edilmiştir. Bunun dışında yerleşimin kurucularının kim olabileceğiyle ilgili bilim insanları ve seyyahların değerlendirmelerine de yer verilmiştir. Sonuç olarak Fenike isminin bölgenin genel ismi olma ihtimali kuvvetli olduğu görülmüştür. Bununla birlikte zaman içerisinde bölgenin iç ve kıyı kesimleri arasındaki isimlendirme farklılıklarının ortaya çıkmasında, buradaki Rumların kültürel olarak Türkleşme sürecinin önemli bir etkisi olduğu düşünülmüştür. Tüm bunlara ek olarak, tarih ve arkeolojinin dışındaki alanlarda yapılacak olan çalışmaların, yerleşimin ilk kurucularının kim olduğu ve Fenike isminin hala daha neden kullanıldığı konularının netleşmesine büyük katkı sunacağı ön görülmüştür.

Anahtar Kelimeler: Finike, Fenike, Liman, Kale, İskele

\begin{abstract}
The purpose of this study is to reveal the roots of the setting Finike located in the southwest of Antalya Bay up against Phoenician region in the Ancient Period, and how the name Finike has reached the present day. Accordingly, written, archaeological, anthropological data associated with the region; archive documents, official publications, travel books, research works, scientific articles, theses and internet resources were used, and data were assested comperatively an sistematically. It is seen that various settlements having variations of the
\end{abstract}


Finike-Fenike Eşleşmesinin Kökenleri ve “Finike” İsminin Günümüze Ulaşması

Phoenike were seen in different periods in the region; however, it is revealed that their nature, size and localization aren't known exactly. Additionally, it is determined that the city and the region were mentioned as Phoenicia in the period from the Byzantine Period to the present, and there are periodic differences in the naming related to locations within the city. Apart from this, the evaluations of scientists and travelers about whom the founders of the settlement were could be included. As a result, it is seen that Phoenicia is likely to be the general name of the region. However, it is thought that the culturally Turkization process of the Greeks there had an important effect on the emergence of naming differences between the inner and coastal areas of the region over time. In addition to all of these, it is concluded that the studies to be carried out in the fields except from history and archaeology the current data of the history and archeology sciences will contribute to the clarification of the subjects regarding who the first founders of the settlement are and why the name Phoenicia is still used.

Keywords: Phineka, Phoenicia, Port, Castle, Pier

\section{Giriş}

Günümüzde Antalya Körfezi’nin güneybatısındaki Finike kenti, bir liman yerleşimi niteliğindedir. Bu limanla Gelidonya Burnu arasındaki kıyı kesim, Finike Körfezi olarak bilinmektedir. ${ }^{1}$ Finike isminin antik Grekçe Phoinikous' tan (Фоıvíò̀us) geldiği ve dolayısıyla yerleşimin en eski kurucularının Fenikeliler olduğu düşünülmektedir. ${ }^{2}$ Bununla birlikte yerleşimin isminin Phoinikos (Фоıvíkoৎ) kelimesinden geldiğini, yerleşimdeki limanın mendireğinin yetersizliğinden dolayı yerleşime en yakın kent olan Limyra (Likçe Zemuri) ${ }^{3}$ Limanı'nın zamanla ön plana çıktığını öne süren araştırmacılar vardır. Bunlara göre Phoinikos kelimesi klzıl renkli at veya kızll renkli davar sürüsü anlamındadır. Bu isim yöredeki hayvanlarla da uyum göstermektedir. Bunun yanında buradaki mevcut buluntular nedeniyle yerleşimin kuruluşu Hellenistik Dönem'in gerisine gidememektedir. ${ }^{4}$ Burada Hellenistik Dönem'in haricinde Roma ve Bizans dönemlerine ait kalıntılar da ortaya çıkarılmıştır. ${ }^{5}$

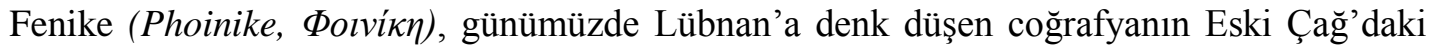
ismidir. ${ }^{6}$ MS 19. yy'ın sonunda Fenikelilerle ilgili ilk bilimsel çalışma yayımlanmış ve Lübnan sahillerindeki palmiye ağaçlarının ününden dolayı bölgeye Phoinike isminin verildiği söylenmiştir. ${ }^{7}$ Ancak daha sonraki çalışmalarda bu iddia çürütülmüş, kelimenin kökeninin Fenike kentlerine özgü, kumaşları mora veya koyu kırmızıya boyama sanayisiyle ilişkili olduğu ortaya

\footnotetext{
${ }^{1}$ Bölgenin haritası için bkz. Harita 1.

${ }^{2}$ Félix Marie Charles Texier, Küçük Asya Coğrafyası, Tarihi ve Arkeolojisi, C.3, Çev: Ali Suat, Enformasyon ve Dökümantasyon Hizmetleri Vakfi Yayınları, Ankara 2002, s.428: Hatice Durgun, "XIX. Yüzyılda Finike'nin İdari ve Sosyo-Ekonomik Yapısından Kesitler", Akademik Incelemeler Dergisi, C.12, S.2, 2017, s.37; Vital Cuinet, La Turquie d'asie Géographie Administrative Statistique Descriptive et Raisonnée de Chaque Province de l'asie Mineure. C.1, Ernest Leroux, Paris, 1892, s.865.

${ }^{3}$ MÖ 5. yy'da kurulmuş olan bu kent için bkz. Ed. Jürgen Borchhardt, Limyra Zemuri Taşları, Çev: Gülay Yümer Arkeoloji ve Sanat Yayınları, İstanbul, 1999.

${ }^{4}$ Cevdet Bayburtluoğlu, "Finike İlçesi ve İlçe Sınırları İçinde Kalan Kalıntılar", Tarih-Kültür-Folklor-Finike, Ed. Ertuğrul Kapusuzoğlu, İstanbul Yayınevi, İstanbul, 2001, s.27.

${ }^{5} \mathrm{Agb}, \mathrm{s.28}$ vd.

${ }^{6}$ Fenike tarihiyle ilgili en güncel bilgiler için bkz. Josette Elayi, The History of Phoenicia, Lockwood Press, Atlanta, 2018.

${ }^{7}$ George Rawlinson, History of Phoenicia, Longmans, Green, and Co, London-New York, 1889, s.1.
} 
çıkarılmıştır. ${ }^{8}$ Fenike kent-devletleri, MÖ 12. yy'dan itibaren Akdeniz kıyılarında ticari koloniler kurmuştur. ${ }^{9}$

Fenikelilerin Antalya Körfezi ve civarındaki varlığına ilişkin herhangi bir yazılı ve arkeolojik kaynak bulunmamaktadır. Ancak şu da belirtilmelidir ki, söz konusu bölgeye komşu olan Çukurova Bölgesi ve çevresinde, antik dönem öncesinden başlayarak bu dönemin sonuna kadarki süreçte Fenikelilere ait maddi kültür kalıntılarına rastlanmıştır. ${ }^{10}$ Ayrıca Geç Tunç Çağı'nda Fenikelilerin atası olan kuzeybatı Sami kökenli Kenanlılara ait ticari mallar, Gelidonya Burnu'ndaki bir gemi batığında ele geçmiştir. ${ }^{11}$ Bunlara ek olarak, bölgede yapılan fiziki antropoloji çalışmalarında bazı toplulukların Sami kökenli olma ihtimali ortaya çıkmıştır. ${ }^{12}$

Bu çalışmada ilk olarak antik dönemdeki yazılı ve arkeolojik kaynaklarda, Finike Limanı ve çevresindeki, Phoinike ve onun varyasyonlarına sahip isimleri olan yerleşimlere ilişkin yapılan atıflar ve de bunlar hakkındaki değerlendirmelere yer verilecektir. Ardından Bizans Dönemi'nden günümüze kadar bölgeyle ilgili isimlendirmelere ve bölgenin demografik yapısına yer verilerek, elde eden veriler bir sonraki sonuç bölümünde karşılaştırılmalı ve sistematik olarak değerlendirilecektir.

\section{Antik Dönem'deki Yazılı ve Arkeolojik Kaynaklarda, Finike Limanı ve Çevresiyle İlişkilendirilen Atıflar ve Bunlara İlişkin Değerlendirmeler}

Volume 12

Issue 5

October

2020

Grek tarihçi Thukydides'in MÖ 5. yy'da kaleme aldığ 1 ve Atina-Sparta mücadelesini anlattığ1 eserde, Atinalıların Karia ve Lykia'ya düzenlediği seferlerin amaçları arasında bölgeden vergi toplamak ve Peloponnesoslular' 1 Phaselis ve Phoinike arasında ticaret yapmalarını engellemek olduğu yazılıdır. ${ }^{13}$

Buradaki Phoinike ismi, eserin çevirilerinde genellikler Fenike olarak gösterilmektedir. ${ }^{14}$ Ancak daha sonra yapılan araştırmalarda buranın, Lykia'da konumlanan bir yerleşim olduğu

\footnotetext{
${ }^{8}$ Sabatino Moscati, Fenikeliler, Çev: Sinem Gül, Dost Kitabevi, 2004, s.27-28. Bu kelimenin, kryı halkı anlamına gelebileceği de iddia edilmektedir. Bkz. Jacques R. Pauwels, Beneath the Dust of Time: A History of the Names of Peoples and Places, Battle Bridge Publications, London-Colombo, 2009, s.47.

${ }^{9}$ Akdeniz'deki Fenike kolonileriyle ilgili bkz. Maria Eugenia Aubet, The Phoenicians and the West: Politics, Colonies and Trade, Cambridge University Press, Cambridge, 1993.

${ }^{10}$ Gunnar Lehmann, "North Syria and Cilicia, c. 1200-330 BCE", Beyond the Homeland: Markers in Phoenician Chronology, Ed. Claudia Sagona. Peeters, Paris, 2008, s.205-246.

${ }^{11}$ Literatürde Gelidonya Batığ $\iota$ olarak bilinen bu batıkla ilgili bkz. George F. Bass-Peter Throckmorton,-Joan Du Plat Taylor-J. B. Hennessy-Alan R. Shulman-Hans-Günter Buchholz, "Cape Gelidonya: A Bronze Age Shipwreck", Transactions of the American Philosophical Society, New Series, C.57, S.8, s.1-177.

${ }^{12}$ Eugen Adolf Hermann Petersen-Felix von Luschan, Reisen in Lykien, Milyas und Kibyratis, Gerold, Wien, 1889, s.210.

${ }^{13}$ Thuk, (Peloponnesos Savaşları, Çev: Furkan Akderin, Belge Yayınları, İstanbul, 2007), II, 69, 1.

${ }^{14}$ Benjamin Jowett, Thucydides translated into English; with introduction, marginal analysis, notes, and indices, C.1, Clarendon Press, Oxford, 1881, s.140: Thomas Hobbes, The History of the Grecian War Written by Thucydides, John Bohn, London, 1843, s.226. Antik Dönem'deki yazarlar da s1k s1k bu kelimeyi, Fenike'den bahsetme amaciyla kullanmıştırlar. Ancak kelimenin Epiros’taki bir kasabayı tanımlamak için kullanıldığı da görülmüştür. Bkz. John Lempriére, A Classical Dictionary: Containing A Copious Account of All the Proper Names Mentioned in Ancient Authors; with the Value of Coins, Weights, And Measures, Used among the Greeks and Romans; and a Chronological

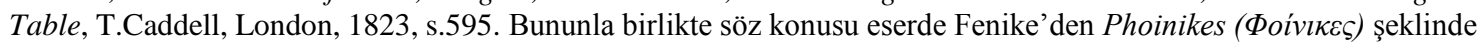
bahsedilmektedir. Bkz. A. W. Dickinson, “A Note on Фoıvíkך in Thucydides 2.69.1”, The Classical Quarterly, C.29, S.1, 1979, s.213, dn.7.
} 
görülmüştür. ${ }^{15}$ Araştırmacıların birisi, dilbilimsel ve coğrafi açıdan bakıldığında, burasının Finike'yle eşleştirilmesi gerektiğini söylemektedir. ${ }^{16}$

Benzer şekilde Grek filozof Plutarkhos, Makedon Kralı III. (Büyük) Aleksandros'un hayatını anlattığ1 eserde, kralın doğuya yaptığı seferi anlatırken, onun Ksanthos'tan sonra Phoinike ve

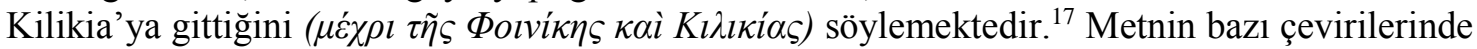
Phoinike, Fenike olarak çevrilmiş ve iki yerleşimin metindeki veriliş sırası değiştirilmiştir. ${ }^{18}$ Bunun üzerine yapılan araştırmalardan bazılarının sonucunda eserin orijinalindeki sıralamasının doğru olduğu, bu bağlamda coğrafi ve dilbilimsel açıdan ilk söylenen yerin Finike'yle eşleştirilmesi uygun görülmüştür. ${ }^{19}$ Araştırmaların birisinde ise özellikle Geç Antik Çağ’a kadar olan kaynaklarda Finike'yle ilişkilendirebilecek herhangi bir atıf bulunmadığından, böyle bir eşleştirme yapmanın doğru olmayacağı belirtilmiştir. ${ }^{20}$ Diğer bir araştırmada ise kralın Ksanthos'tan sonra Lykia kıyılarına uğramadan Phaselis'e geçtiği vurgulanmıştır. ${ }^{21}$

Yukarıdaki isimle ilişkilendirilen başka bir yer ise Romalı tarihçi Titus Livius'un Ab Urbe Condita isimli eserinde, MÖ 2. yy'ın başında Roma Cumhuriyeti ve müttefikleriyle Seleukos Krallığı ve müttefikleri arasında yapılan savaşı anlattı̆̆ı kısımda geçen, Patara'nın iki mil doğusunda bulunan Latince Phoenicus ismindeki limandır. ${ }^{22}$ Bazı araştırmacılar yaptıkları değerlendirmelerin sonucunda bu limanının, Kalkan' $\mathrm{da}^{23}$ veya Kemer'de ${ }^{24}$ olabileceğini ileri sürmüştürler. Bunlardan bazıları da söz konusu limanın Thukydides'in bahsettiği Phoinike olabileceğini iddia etmiştirler. ${ }^{25}$

Doğu Akdeniz'deki Hristiyan kentlerin ve kiliselerin görevlileri hakkında bilgi ve hiyerarşik sıralamasını veren resmi kilise belgelerini içeren Notitiae Episcopatuum'da, Lykia'da yaşayan

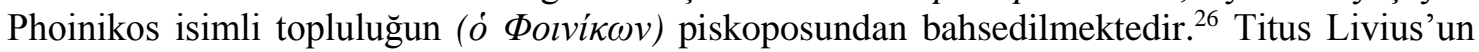

\footnotetext{
${ }^{15}$ K. Buschmann, "Die Expedition des Melesander nach Lykien 430/29 v.Chr. und die Lokalisierung von Фoıvıкn", Epigraphica Anatolica, S.12, 1988, s.1-8; M. Zimmermann, "Noch einmal Thuk. II 69 und ФOINIKH", Hermes, S.121, 1993, s. 266-275; Simon Hornblower, A Commentary on Thucydides, C.1, Clarendon Press, Oxford 2003, s.355-356.

${ }^{16}$ Dickinson, agm.

${ }^{17}$ Plut, Bio, Aleks, (Martin Hammond, Thucydides: The Peloponnesian War, Oxford University Press, New York, 2009) $17,3$.

${ }_{18}$ Martin Hammond, age, s.109; Richard Crawley, The History Of Peloponnesian War by Thucydides, E. P. Dutton Company and Inc.-J. M. Dent and Sons Limited, New York-London, 1950, s.167.

${ }^{19}$ Freya Stark, "Alexander's March from Miletus to Phrygia", The Journal of Hellenic Studies, C.78, 1958, s.114, dn.23: Peter Green, Alexander of Macedon 356-323 B.C.: A Historical Biography, University of California Press, Berkeley, Los Angeles, London 2013, s.202.

${ }^{20}$ Christian Le Roy, "Alexandre À Xanthos", Actes du Colloque sur la Lycie antique, Libr. d'Amérique et d'Orient Adrien Maisonneuve, Paris 1980, s.53.

${ }^{21}$ Albert Brian Bosworth, Conquest and Empire: The reign of Alexander the Great, Cambridge University Press, New York 2009, s.50.

${ }^{22}$ Titus Livius, (History of Rome, Volume XI, Books 38-39, Çev: Evan T. Sage, Harvard University Press, Cambridge, Massachusets, 1936) XXXVII, 16, 6. Bu isim aynı zamanda Erythrai, Messenia, Kythera, Marmarika ve Girit'te bazı limanlara da verilmiştir. Bkz. Ed. Hubert Cancik-Helmuth Schneider, Brill's New Pauly : Encyclopaedia of the Ancient World: Antiquity, C.11, Brill, Leiden-Boston, 2007, s.619-620.

${ }^{23}$ Antiquities of Ionia, C.3, The Society of Dilettanti, London 1840, s.80; Francis Beaufort, Karamania: Or, A Brief Description of the South Coast of Asia-Minor and of the Remains of Antiquity. With Plans, Views, \&c. Collected During a Survey of that Coast, Under the Orders of the Lords Commissioners of the Admiralty, in the Years 18111812, R. Hunter, London, 1817, s.7; Buschmann, agm; William Martin Leake, Journal of a Tour in Asia Minor,: With Comparative Remarks on the Ancient and Modern Geography of that Country, John Murray, London, 1824, s.184.

${ }^{24}$ Hornblower, age, s.356.

${ }^{25}$ Buschmann, agm, s.4-6; Trevor Bryce, The Lycians in Literary and Epigraphic Sources, C.1, Museum Tusculanum Press, Copenhagen, 1986, s.239.

${ }^{26}$ Walther Ruge, "Phoinix 15", Realencyclopädie der classischen Altertumswissenschaft, c.20 K.1, Metzler, Ed. Karl Mittelhaus, Stuttgart, 1943, s.428-431.
} 
bahsettiği yerin Kalkan'da olduğunu savunan araştırmacılardan birisi, bu topluluğun söz konusu belgelerde, o dönemki Patara sakinlerinden sonra yer almasından dolayı topluluğun yaşadığı yerle Livius'un bahsettiği yerin aynı olduğunu iddia etmektedir. ${ }^{27}$

Bunun dışında Limyra kentinin nekropolündeki MÖ 4. yy'a ait kaya mezarlarından birinin kapısının üstünde Likçe bir yazıt bulunur. Yazıttan anlaşıldığı kadarıyla bu bir aile mezarlığıdır. ${ }^{28}$ $\mathrm{Bu}$ yazıtın altında antik Grekçe Фoívıкos Topí $\omega$ şeklinde okunan bir yazıt vardır ve bu yazıtın üstteki yazıta sonradan eklenmiş olduğu düşünülmektedir. Bu nedenle yazıt MÖ 4-3.yy'a tarihlenmiştir. ${ }^{29}$ Yazıttaki sözcüklerin ticaret yapmak amacıyla buraya daha önce uğramış yabancılara ilişkin bir anımsatma olduğunun bilinmesiyle birlikte; ${ }^{30}$ yazıtın Fenike'nin önemli kent-devletlerinden birisi olan Tyros'tan gelmiş birine ait olabileceği de düşünülmektedir. ${ }^{31}$

Öte yandan ünlü coğrafyacı Strabon, Geographika isimli eserinde bölgeden bahsederken Hiera Burnu'yla Olbia arasında Olympos isminde büyük bir kent ve kentle aynı adı taşıyıp Phoinikous olarak da adlandırılan bir dağ bulunduğunu, buradan sonra da bir deniz kıyı şeridi olan Korykos'un geldiğini söylemektedir. ${ }^{32}$ Bunun yanı sıra MS 3. yy'ın ikinci yarısına tarihlenen Stadiasmus Maris Magni isimli periplousta da Strabon'un verdiği bilgiler kısmen doğrulanmaktadır. Burada Korykos'tan Phoinikous'a olan yolun uzunluğu verilmiş; Olympos'tan ise sadece dağ olarak bahsedilmiştir. ${ }^{33}$

Araştırmacılar bahsi geçen dağın, Antalya Körfezi'nin güneybatısında bulunan Musa Dağı ve veya Tahtalı Dağı olduğunu düşünmektedirler. ${ }^{34}$ Buranın Phoinikos'la eşleşebileceğini düşünenler olduğu gibi; ${ }^{35}$ Phoinike'yle eşleşebileceğini düşünenler de mevcuttur. ${ }^{36}$

MS 6. yy'da Pharroa'da doğan Sionlu Aziz Nikolaos'un hayatının kaleme alındığı Vita

Volume 12

Issue 5

October 2020 Nicolai Sionitae isimli eserde, onun Kudüs'e yaptı̆g haç yolculuğundan dönerken içinde bulunduğu gemi Lykia açıklarında firtınaya yakalanmıştır. İlgili bölümün anlatıldığı kısımda

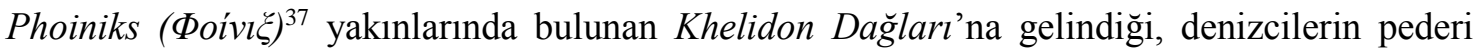

\footnotetext{
${ }^{27}$ Buschmann, agm, s.3.

28 Zeynep Kubay, Die Felsgraber vol Limyra in Lykien (Likya'da Limyra Kaya Mezarları), (İstanbul Teknik Üniversitesi Fen Bilimleri Enstitüsü, Yayımlanmamış Doktora Tezi), İstanbul, 1996, s.526.

${ }^{29}$ Michael Wörrle, "Die griechischen Sepulkralinschriften von Limyra", Limyra: Studien zu Kunst und Epigraphik in den Nekropolen der Antike, Ed. Jürgen Borchhardt-Anastasia Pekridou-Gorecki, Phoibos Verlag, Wien, 2012, s.419; TAM I (Tituli Asiae Minoris. Vol. 1, Tituli Lyciae lingua Lycia conscripti, Ed. Ernst Kalinka, Alfredi Hoelderi, Vindobonae, 1901), 115.

${ }^{30}$ Thomas Abel Brimage Spratt-Edward Forbes, Milyas, Kibyratis ve Likya'da Yolculuklar, C.1, Çev: Doğan Türker, Suna - İnan Kıraç Akdeniz Medeniyetleri Araştırma Enstitüsü, Antalya, 2008, s.161.

${ }^{31}$ Wörrle, agb, s.419. Tyros tarihi için bkz. Walter Bruce Fleming, The History of Tyre, Columbia University Press, New York, 1915.

${ }^{32}$ Strab, Geog (Antik Anadolu Coğrafyası (Geographika: XII-XIII-XIV), Çev: Adnan Pekman, Arkeoloji ve Sanat Yayınları, 2001), XIV, 3, 8. Hiera Burnu, Gelidonya'yla eşleştirilmektedir. Bkz. age, s.318. Olbia'nın ise yapılan incelemeler sonucunda Kemer'de olduğu tespit edilmiştir. Bkz. Sencer Şahin, "Pamfilya/Likya Sınır Kentleri: Olbia ve Diğerleri”, Likya İncelemeleri, C.1, Ed. Sencer Şahin-Mustafa Adak, Arkeoloji ve Sanat Yayınları, İstanbul, 2002, s.30-31.

${ }^{33}$ SMM (Nihal Tüner, Lykia'nın Yerleşim Coğrafyasında Yeni Lokalizasyonlar, (Akdeniz Üniversitesi Sosyal Bilimler Enstitüsü, Yayımlanmamış Doktora Tezi), Antalya, 2002, s.145), 228.

${ }^{34} \mathrm{Bu}$ konudaki tartışmalar için bkz. Elif Uğurlu, "Olympos ve Zeniketes'in Kalesinin Lokalizasyonu”, Adalya, S.10, 2007, s.1-23; Mustafa Adak, "Lokalisierung von Olympos und Korykos in Ostlykien", Gephyra, C.1, 2004, s.27-51.

${ }^{35}$ Bryce, age, s.239.

${ }^{36}$ Zimmermann, agm.

${ }^{37} \mathrm{Bu}$ kelime, Fenikeli, Zümrüdü Anka Kuşu, palmiye ağacı, hurma, bir çeşit müzik enstrümanı, mor veya koyu kırmızı, otsu bir bitki, bir tür fiğ gibi anlamlar içermektedir. Bkz. James Donnegan, A New Greek and English Lexicon;
} 
Phoiniks'te indiremeyeceklerini söyledikleri, bunun üzerine pederin en azından Andriake'de ${ }^{38}$ inmek istediği, denizcilerin de bunun reddedip onu ancak Rodos'ta indirebileceklerini söyledikleri yazmaktadır. ${ }^{39}$

Bizans soylusu ve aynı zamanda keşiş ve kronik yazarı olan Theophanes de MS 654/655 yılında Phoiniks'te Bizans donanmasıyla Arap donanması arasında bir savaş meydana geldiğini ve Bizans donanmasının ağır bir yenilgiye uğradığını söylemektedir. ${ }^{40}$ Ayrıca yazar, MS 715'te Arapların bölgeden, gemicilikte kullanılan keresteleri tedarik ettiklerini ve aynı zamanda burada gemi direklerinin üretildiğini de eklemiştir. ${ }^{41}$

MS 10. yy'ın ilk yarısında Bizans'ta hüküm süren imparator Konstantinos Porphyrogenitos, imparatorluğun eyaletlerindeki olaylarla ilgili bilgilere yer verdiği $D e$ Thematibus isimli eserinde, Güney Anadolu kıyılarını kapsayan Kibyrrhaiotai Theması içindeki Lykia'da, Myra ve Phaselis arasında aynı isimde bir kent ve nehir olduğunu belirtmiştir. ${ }^{42}$ Bazı araştırmacılar, coğrafi ve dilbilimsel nedenlerden dolayı, yerleşimin Finike'yle eşleştirilmesi gerektiğini ifade etmiştirler. ${ }^{43}$ Öte yandan MS 1. yy'da Patara'da dikilen yol anıtındaki (Patara Stadiasmos) güzergâhlardan ikisinin Limyra'da bittiği, ikisinin de buradan başladığı görülmektedir. ${ }^{44}$ Anıt üzerinde yapılan ayrıntılı bir filolojik çalışma sonunda Phoiniks isimli liman, Finike Limanı'yla eşleştirilmiştir. ${ }^{45}$

Tüm bunlardan yola çıkarak Phoinike sözcügünün ele aldığımız bölgedeki yerleşimin genel adı olduğu ve kaynaklarda Phoiniks şeklinde bahsedilen limanın - Myra'nın Andriake isimli limana sahip olmasından dolayı - Limyra'ya ait bir liman olduğu şeklinde bir önerme de mevcuttur. ${ }^{46}$

Principally on the Plan of the Greek and German Lexicon of Schneider: the Words Alphabetically Arranged; Distinguishing such as Are Poetical, of Dialectic Variety, or Peculiar to Certain Writers and Classes of Writers; with Examples, Literally Translated, Selected from the Classical Writers, Hilliard, Gray \& Co.-G. \& C. Carvill \& Co, Boston-New York, 1840, s.1348. Karia'daki Rhodos Peraiası'nda bu isme sahip bir dağ ve kale bulunmaktadır. Bkz. Ed. Hubert Cancik-Helmuth Schneider, age, s.173

${ }^{38}$ Geç Antik Dönem'de Myra'ya ait liman yerleşimidir Bkz. Nevzat Çevik, Süleyman Bulut, Çakır Afşin Aygün, "Myra'nın Limanı Andriake", Byzas, C.1 S.19, 2014, s.225-243.

39 VNS (Ceren Pilevneli, M.S. IV.-VII. Yüzyıllarda Myra (Lykia) ve Egemenlik Alanında Hristiyanlık, (Marmara Üniversitesi Türkiyat Araştırmaları Enstitüsü, Yayımlanmamış Yüksek Lisans Tezi), İstanbul, 2013, s.64-65), 37.

40 Theoph. Chron, (The Chronicle Of Theophanes, Çev: Harry Turtledove, University of Pennysylvania Press, Philadelphia, 1982) s.346. Bazı kaynaklar bu limanın, Mısır'daki İskenderiye Limanı olduğunu söylemektedir. Bkz. Murat Öztürk, "Zâtüssavârî", TDV İslâm Ansiklopedisi, TDV İslâm Araştırmaları Merkezi, 2013, https://islamansiklopedisi.org.tr/zatussavari (E.T. 10.07.2020).

${ }^{41}$ Theoph. Chron, s.385.

${ }^{42}$ Konstant. Porphy, De Thematibus (De thematibus et de administrando imperio, Ed. Immanuel Bekkerus, Ed. Weberi, Bonnae, 1840), s.16.

${ }^{43}$ Buschmann, agm, s.3.

${ }^{44} \mathrm{Bu}$ güzergâhlar Myra-Limyra, Arykanda-Limyra; Limyra-Arneia, Limyra-Korydalla şeklindedir. Anıtla ilgili genel bilgi için bkz. Sencer Şahin, "Stadiasmus Patarensis: Likya'nın Roma Yolları", Arkeoloji ve Sanat Dergisi, S.136, 2011, s.98-103. Güzergâhların haritalarından bir örnek için bkz. Harita 2.

${ }^{45}$ Sencer Şahin-Mustafa Adak, Stadiasmus Patarensis: Itinera Romana Provinciae Lyciae, Ege Yayınları, İstanbul, 2007, s.210, 265.

${ }^{46}$ Antony G. Keen, Dynastic Lycia: A Political History of the Lycians and their Relations with foreign Powers, c. $545-$ 362 B.C., Brill, Leiden, Boston, Köln 1998, s.227 ve dn.16. 


\section{Bizans Dönemi’nden Günümüze Kadar Bölgeyle İlgili İsimlendirmeler ve Bölgenin Demografik Yapısı}

Bizans İmparatoru I. Manuel Kommenos, 1176'da Selçuklularla yapılan Myriokephalon Savaşı öncesinde önce 1169 yılında Cenova, ardında da 1170 yılında Pisa' yla yaptığı antlaşma neticesinde Lykia'nın kıyı kesiminde İtalyan denizcilere imtiyazlar sağlamıştır. I. Andronikos döneminde ise bu ilişkiler bozulmuş, bunun üzerine Pisalılar bölgede korsanlığa başlamıştırlar. Bu dönemde Finike Körfezi, Pisalılar Koyu olarak bilinmektedir ve bölgedeki Phoenix ${ }^{47}$ ise korsanların en büyük deniz üssü haline gelmiştir. ${ }^{48} 1191$ 'de Fransa Kralı Philippe Augustus'un III. Haçlı Seferi'nden dönerken buradaki dört İtalyan gemisini tahrip ettiği bilinmektedir. ${ }^{49}$

Selçuklu Hükümdarı I. Gıyaseddin Keyhüsrev, 1207 yılında Antalya'yı fethetmiştir. ${ }^{50}$ Lykia'nın iç kısımları uzun süreden beri Türklerin egemenliği altındadır; ancak sahil kesimleri yabancı gemi ve korsanların barınağı olmayı sürdürmüştür. Sultan I. Alaaddin Keykubat'ın isteği üzerine bölgeye 1220'lerde bir deniz seferi düzenleyen Antalya Subaşısı Mübarizeddin Ertokuş, Muğla'dan Silifke'ye kadar olan bölgede düşmana ait yaklaşık kırk kale ve korsan üssünü ele geçirmiştir. ${ }^{51}$

Selçukluların zayıflamasıyla birlikte 13. yy'ın ikinci yarısında başlayan II. Anadolu Beylikleri Dönemi'nin başında Lykia'nın kıyı kesimleri, Menteşeoğulları Beyliği'nın egemenlik sahası

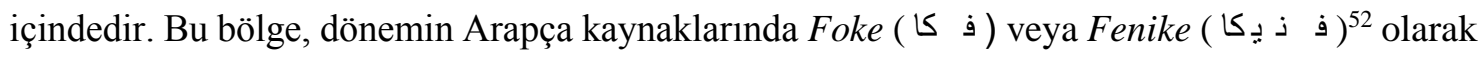
adlandırılmış, beyliğin kurucusu Menteşe Bey'in 14. yy'ın başındaki ölümünden sonra, oğullarından birisi olan Kirman Bey'in bölgede hüküm sürdüğü görülmüsstür. ${ }^{53}$ Bunun yanı sıra 1320'lerde Menteşe Bey'in torunu Orhan'ın Foke/Fenike'nin ${ }^{54}$ sınırları içinde bulunan ve bölgeyle aynı ismi taşıyan kenti, beyliğin merkezi yaptığı şeklindeki bilgiler de günümüze kadar ulaşmıştır ${ }^{55}$.

13-14. yüzyıl arasındaki bu geçiş döneminde, İtalyan denizcilerin kayıtlarında bölgedeki bazı limanlara İtalyan gemilerinin girmesinin ve buralara demirlemesinin tavsiye edilmediği

\footnotetext{
${ }^{47} \mathrm{Bu}$ yüzyıldaki portolan haritalarda bölge, finica, Finika olarak geçmektedir. Bkz. Keen, age, s.226, dn.13.

${ }^{48}$ Muhammet Güçlü, "Selçuklulardan Cumhuriyet'e Kumluca (Antalya) Bölgesi”, Türkiyat Araştırmaları Dergisi, S.22, 2007, s.224.

${ }^{49}$ İlhan Erdem, "Ortaçağ Sonlarında Likya Levant Ticareti ve Türkmenler (12.-15. YY.)”, III. Likya Sempozyumu 7 10 Kasım 2005, Sempozyum Bildirileri, C.I, İstanbul, 2006, Ed. Kayhan Dörtlük, Tarkan Kahya, Burhan Varkıvanç, Suna-İnan Kıraç Akdeniz Medeniyetleri Araştırma Enstitüsü, Antalya, 2006, s.246.

${ }^{50}$ Antalya'nın fetih süreci için bkz. Mahmut Demir, “Antalya'nın Türkiye Selçukluları Tarafından Fethi”, Cedrus, S.7, 2018, s.555-571.

${ }^{51}$ İlhan Erdem, "Bir Ortaçağ Kenti Antalya: Geç Antik Dönemden Selçukluların Sonuna Genel Bir Yaklaşım (II)", Adalya, S.6, 2003, s.293-296.

${ }^{52} \mathrm{Bu}$ yüzyıla ait portolan haritalarda bölgenin la finica şeklinde adlandırıldığı görülmüştür. Bkz. Keen, age, s.226, dn.13.

53 İsmail Hakkı Uzunçarşılı, Anadolu Beylikleri ve Akkoyunlu, Karakoyunlu Devletleri, C.1, Türk Tarih Kurumu Basımevi, Ankara, 2003, s.71.

${ }^{54} \mathrm{Bu}$ yüzyılın portolan haritalarında bölge finica, Finigha şeklinde isimlendirilmiştir. Bkz. Keen, age, s.226, dn.13.

55 Uzunçarşı1l, age, s.73; Yaşar Yücel, XIII-XIV. Yüzyıllarda Kuzey-Batı Anadolu Tarihi-Çoban-Oğulları, CandarOğulları Beylikleri, Türk Tarih Kurumu Basımevi, Ankara, 1980, s.200.
} 
görülmüştür. Bunun sebebi, dağlı kısımlarda Rumlarla Türklerin yerleşik olarak yaşamalarıdır. ${ }^{56}$

Öte yandan bu dönemde Hamidoğulları Beyliği'nin Antalya kolunun Teke İli olarak anılmaya başladığ 1 da bilinmektedir. ${ }^{57} \mathrm{Bu}$ ismin nerden geldiğiyle ilgili dört teori ortaya atılmıştır. Bunlar: erkek keçi anlamına gelen teke sözcügünnden türemiş olmas1, Selçuklulardan sonra bölgede hüküm süren Teke Bey'den kaynaklanması, bölgedeki Teke Yörükleri'nden kaynaklanması ve Hamidoğullarının, Tekeoğullarının mensup olduğu Teke aşiretinin bir bölümü olmasından kaynaklanması şeklindedir..$^{58}$

Kaynaklarda, 1330 yılında Finika/Fenike/Foke kentinde, Antalya'y1 yöneten Hızır Bin Dündar'ın tayin ettiği, Hamidoğulları'na bağlı bir Menteşe Beyi olduğu ve bu beye ait kırk bin atlı askerin bulunduğuna dair bilgiler vardır..$^{59}$

Teke İli, Osmanlı Hükümdarı Yıldırım Bayezid tarafından 1393'te zapt edilmiş ve aynı yıl kurulduğu kabul edilen Anadolu Eyaleti'ne bağlanmıştır. ${ }^{60}$ Bölge 1420'lerden itibaren Teke Sancă̆ı olarak adlandırılmaya başlanmıştır. ${ }^{61}$

Öte yandan Osmanlı İmparatorluğu'nun Rodos'u kuşatmasının başlangıç yılı olan 1479'da Mesih Paşa komutasındaki Osmanlı donanmasının Fenike Limanı'na ${ }^{62}$ uğrayıp asker topladığ bir sene sonra ise Halikarnas (Bodrum) Kalesi'ni zapt etmek için limanın üs olarak kullanıldığ 1 bilinmektedir. $^{63}$

\subsection{Yeni Çăg}

16. yy’a ait resmi kayıtlarda, Teke Sancă̆g'ndaki dağlık bölgelerde yaşayan yörükler arasında Şehr-i Fenike Yörükleri'nin olduğu yazılıdır. ${ }^{64}$ Piri Reis'in bu yüzyılın başında yazdığı ve

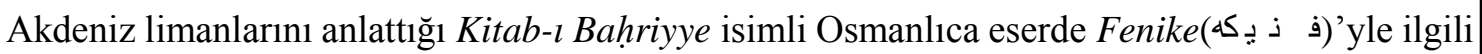

\footnotetext{
${ }^{56}$ Muhammet Güçlü, "Doğu Akdeniz'de Bir Liman Kenti: Finike”, Osmanlı Dönemi Akdeniz Dünyası, Ed. Haydar Çoruh-M. Yaşar Ertaş-M. Ziya Köse, Yeditepe Yayınları, İstanbul, 2011, s.419.

${ }^{57}$ İsmail Hakkı Uzunçarşı11, Osmanlı Tarihi, C.1, Türk Tarih Kurumu Basımevi, Ankara, 1988, s.62-63.

${ }^{58} \mathrm{Bu}$ konudaki tartışmalar için bkz. Abdüllatif Armağan, XVI. Yüzyılda Teke Sancă̆ (Tapu-Tahrir Defterlerine Göre), (Ankara Üniversitesi Sosyal Bilimler Enstitüsü, Yayımlanmamış Doktora Tezi), Ankara, 1996, s.18-25.

${ }^{59}$ Uzunçarşı11, Anadolu Beylikleri, s.73; Paul Wittek, Menteşe Beylı̆̆̂̀i: 13-15 İnci Asırda Garb̂̂ Küçük Asya Tarihine Ait Tetkik, Çev: Orhan Şaik Gökyay, Türk Tarih Kurumu Basımevi, Ankara, 1944, s.53.

${ }^{60}$ Muhammet Güçlü, Doğu Akdeniz'de, s.420.

${ }^{61}$ Durgun, agm, s.40.

${ }^{62} \mathrm{Bu}$ yüzyıldaki portolan haritalarda bölge, finica, golfo de Firica, foxe de fenicha, Фoívıкaৎ olarak gösterilmektedir. Bkz. Keen, age, s.226, dn.13.

${ }^{63}$ İsmail Hakk1 Uzunçarșıl1, Osmanlı Tarihi, C.2, Türk Tarih Kurumu Basımevi, Ankara, 1988, s.145-146.

${ }^{64}$ Serkan Sarı, XV-XVI. Yüzyıllarda Menteşe, Hamid ve Teke Sancă̆ Yörükleri, (Süleyman Demirel Üniversitesi Sosyal Bilimler Enstitüsü, Yayımlanmamış Doktora Tezi), Isparta, 2008, s. 357-358.

${ }^{65} \mathrm{Bu}$ kalenin, 1361-1373 yılları arasında Teke'de Luzinyanlıların egemenliği sürerken, Cenevizliler tarafından yapıldığı sanılmaktadır. Bkz. Uzunçarşıll, Osmanlı Tarihi, C.1, s.62; T. Mikail P. Duggan-Çakır Afşin Aygün, "The Medieval and Later Port of Myra/Stamira - Taşdibi”, Byzas, C.1, S.19, 2014, s.263.
} 
önlerinin iyi demir yeri olduğu belirtilmektedir. Bölgede üç büyük akarsu vardır ve ortadakinin kaynağı, kıyıdan dört mil kadar içerdeki Fenike Köyü'dür. ${ }^{66}$

Öte yandan yerleşim bu yüzyılın başından itibaren idari kayıtlarda Elmalı kazasına bağlı Finike nahiyesi olarak geçmektedir. ${ }^{67} \mathrm{Bu}$ yüzyılda nahiyede önemli gelişmeler meydana gelmiştir. Örneğin Venedikli korsanlar, 1571'de, yerleşimin Yılanbaşı İskelesi ${ }^{68}$ olarak bilinen iskelesine saldırmıştırlar. ${ }^{69}$ Bununla birlikte Osmanlı İmparatorluğu'nun Kıbrıs'1 fethetmek için

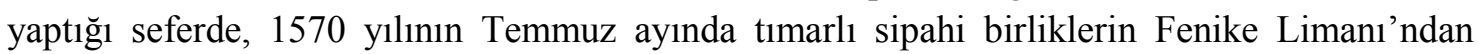
kalkan gemilerle Kıbrıs'a geçtikleri tarihi kaynaklarda yer almaktadır. ${ }^{70}$

17. yy'da Finike, Elmalı'dan ayrı bir nahiye statüsündedir. ${ }^{71} \mathrm{Bu}$ dönemde bölgede görülen Celâli İsyanları'nın uzantısı olarak, 1605 yılında Teke Sancakbeyi Ahmed'in oğlu Mehmed Çavuş, çevresine topladığı bin kadar eşkıya ve sekbanla yöredeki köyleri yağmalamış, hatta Finike Kalesi'ni de ele geçirerek Teke birlikleriyle savaşmış ve bunun sonucunda birçok köy halk1 yerinden olmuştur. 1609 y1lında ise eski Teke Sancakbeyi İbrahim Bey'in, birkaç yüz kişilik grupla başlattığı isyan yüzünden, Yılanbaşı Kalesi'ne sığındığı görülmüştür. ${ }^{72}$

1606 yılının 6 Haziran gününün gece yarısı, Toskana Grandukası'na bağlı Aziz Stephanos Şovalyeleri Tarikatı'nın korsanları, az sayıda nöbetçi ve topçu tarafından korunan kaleye baskın yapmıştır. Kaledeki halk büyük bir direniş göstermiş; ancak korsanlar kaledeki on topu ve kırk kadar esiri alarak, Osmanlı birliklerinin kaleye gelmesi üzerine yerleşimi terketmiştirler. ${ }^{73}$ Tarikat kayıtlarına göre Türkler çatışmayı kaybedeceklerini anlayınca toplu olarak intihar etmiştirler. ${ }^{74}$

Volume 12

Bu yüzyılın ortalarında bölgeyi gezen Evliya Çelebi, Finike Kalesi ve Limanı'na ilişkin izlenimlerini anlatırken, yerleşimin tarihiyle ilgili bilgiler de vermektedir. Öncelikle kalenin Cenevizliler tarafindan kurulduğunu, daha sonra burayı Tekeoğlu Ahmet Bey'in fethettiğini, Osmanlı Hükümdarı Orhan Bey tarafından Teke Bay olarak isimlendirdiğini ve bundan dolayı bölgenin Teke olarak isimlendirildiğini söylemektedir. Daha sonra bu kalenin deniz kıyısında tehlikeli bir derbent olduğunu ve buradaki Mısır İskelesi'ne her yıl çok sayıda gemi gelip onlardan gümrük alındığından bahsetmektedir. Limanın ucunda deniz içinde sağlam bir

\footnotetext{
${ }^{66}$ Ed. Yavuz Senemoğlu, Kitab’ı Bahriyye: Denizcilik Kitabl, C.2, Tercüman Gazetesi Yayınları, İstanbul, 1973, s.285-286; Piri Reis, Kitäb-i Bahriye (Book on Navigation), The Walters Art Museum, Baltimore, 2011, 336a-336b. Liman ve çevresini gösteren harita için bkz. Harita 3.

${ }^{67}$ Armağan, agt, s.102-103.

${ }^{68}$ Buras1, günümüzde ilçede yer alan İskele Mahallesi'ne denk düşmektedir. Söz konusu iskelenin bulunduğu akarsuyun çizdiği kavis, yılanbaşına benzemekte olup, muhtemelen bundan dolayı iskeleye bu isim verilmiştir. Bahsi geçen mevkinin uydu görüntüsü için bkz. Harita 4.

69 Behset Karaca, XV ve XVI. Yüzylllarda Teke Sancağ , (Ondokuz Mayıs Üniversitesi Sosyal Bilimler Enstitüsü, Yayımlanmamıș Doktora Tezi), Samsun, 1997, s.75, dn.425.

70 İsmail Hakkı Uzunçarşı1lı, Osmanlı Tarihi, C.3, Türk Tarih Kurumu Basımevi, Ankara, 1988, s.32.

${ }^{71}$ Armağan, agt, s.103.

${ }^{72}$ Mikail Acıpınar, “Güney Anadolu Kıyılarında Hristiyan Korsanlar (1604-1608)”, Akademik Bakış, C.11, S.21, 2017, s.201.

${ }^{73}$ Agm, s.195-196. Saldırının tasvir edildiği minyatür için bkz. Resim 1.

${ }^{74}$ Nevzat Çevik, "Rhodiapolis ve Kumluca Sınırları İçindeki Diğer Antik Yerleşimler”, Arkeolojisi, Tarihi, Doğası ve Tarımıyla Kumluca - Rhodiapolis, Ed. Nevzat Çevik, Kumluca Belediyesi Yayınları, Antalya, 2008, s.12.
} 
mendirek kulesi olduğunu, bunun kale dibinde 300 hanelik bir varoşu bulunduğunu, bu mahallenin yardıma muhtaç bir durumda olduğunu yazmaktadır. ${ }^{75}$

Akdeniz'deki korsanların Mısırlı tüccarlara karşı düzenledikleri yağma nedeniyle Mısır'da kıtlık baş göstermesi ve tüccarların gemilerinin zarar görmesi üzerine Osmanlı Divan-1 Hümayun'u, 1719 yılının başında, sınırları içinde gemi yapımı olduğu bilinen yerleşimlerin yöneticilerinden tüccarlar için kalyon haricinde gemi inşa etmelerini istemiştir. Bu yerleşimler arasında Finike de vardır; ancak resmi belgelerde kentin Fenike şeklinde yazıldığı görülmüştür. ${ }^{76}$

Öte yandan bölge bu yüzyılda, Teke Yörükleri’nin halka yapmış olduğu yağma ve eziyetlerle bilinmektedir. ${ }^{77} 1760$ 'ta Elmalı Kazası'ndan satın alınıp Rodos'a gönderilecek olan tahıllar, Finike İskelesi'ne indirilirken yağma edilmiş; ancak daha sonra zabtiye tarafından geri alınmış ve suçlular cezalandırılmıştır. ${ }^{78}$

\subsection{Yakın Çăg}

Osmanlı İmparatorluğu'nun 1831 yılındaki idari taksimatıyla birlikte Teke Sancağı, merkezi Kütahya olan Anadolu Eyaleti'nin livası haline gelmiştir. ${ }^{79}$ Tanzimat Fermanı'nın ilanıyla birlikte yapılan idarî düzenleme sonucunda Teke Sancağı 1847 'de, Konya merkezli Karaman Eyaleti'ne bağlanmıştır. ${ }^{80}$

1864 tarihli İdare-i Vilayet Kanunu'nun yürürlüğe konmasının ardından 1867'de yapılan düzenlemeyle Teke Sancağı, Konya Vilayeti'nin sancaklarından biri haline getirilmiş, Finike ise Elmalı Kazası'na bağlı bir nahiye statüsü kazanmış ve buranın zabıta işleri çevresindeki diğer nahiyelerle ortaklaşa yürütülmüştür. ${ }^{81} \mathrm{Bu}$ dönemde Finike'de yapılan sosyo-ekonomik çalışmaların birisinde, yerleşimdeki üç bin kişilik nüfusun büyük bir bölümünün Rum Ortodoks Hristiyanlardan oluştuğu ve bunların ticaret yapmak için adalardan geldiği ifade edilmektedir. ${ }^{82}$ Bununla birlikte bölgede araştırma yapan bazı kişilerin yazdığ ${ }^{\prime}$ anı kitaplarında, Rumlarla Türklerin dağlık bölgelerde bir arada yaşadıklarına ilişkin bazı anektodlar olduğu görülmektedir. ${ }^{83}$

1909 yılında Finike sahilinde Kal'a adıyla anılan mevkide bir hükümet konağı inşa edilmiş ve buraya İskele ismi verilmiştir. Sahilden yarım saat mesafe içerde yer alan İskele isimli mevkinin ismi de Reşadiye olmuştur. ${ }^{84} 1914$ yılındaki idari düzenlemede Teke Sancağ içinde

\footnotetext{
${ }^{75}$ Ed. Seyit Ali Kahraman, Günümüz Türkçesiyle Evliyâ Çelebi Seyahatnamesi: Kütahya, Manisa, İzmir, Antalya, Karaman, Adana, Halep, Şam, Kudiis, Mekke, Medine, C.9, K.1, Yap1 Kredi Yayınları, İstanbul, 2011, s.299-300.

76 BOA (Devlet Arşivleri Başkanlığı Osmanlı Arşivi), Bab-ı Asafi, Defterleri, (BOA. A.\{DVNSMHM.d...), (127/1290-1307), 02 Ocak 1719 (1131.S.10).

${ }^{77}$ Hatice Durgun, XIX. Yüzyılda Teke Sancağı'na Bağlı Elmalı Kazası'nın Sosyo-Ekonomik Yapısı (1839-1914), (Akdeniz Üniversitesi Sosyal Bilimler Enstitüsü, Yayımlanmamış Doktora Tezi), Antalya, 2014, s.13.

${ }^{78}$ BOA, Cevdet Zabtiye, (BOA. C. ZB), (47/2341), 29 Haziran 1760 (1173.Zk.15).

${ }^{79}$ Fazıla Akbal, "1831 Tarihinde Osmanlı İmparatorluğu'nda İdari Taksimat ve Nüfus”, Belleten C.15, S.60, 1951, s.620.

${ }^{80}$ Durgun, agm, s.41-42.

${ }^{81}$ Durgun, agm, s.42; Güçlü, Doğu Akdeniz'de, s.426.

${ }^{82}$ Cuinet, age, s.865.

${ }^{83}$ Ernest Krickl, 1892 Lykia Günlüğü, Çev: Z. Zühre İlkgelen, Suna ve İnan Kıraç Vakfı Yayınları-Arkeoloji ve Sanat Yayınları, İstanbul, 2005, 124-136.

${ }^{84}$ Durgun, agt, s.71.
} 
müstakil liva haline dönüşen Antalya'nın arazisinin geniş olması ve bununla birlikte yönetiminin de kolaylaştırılmak istenmesi nedeniyle Finike Nahiyesi, kaza statüsüne sahip olmuştur. ${ }^{85}$ Aynı yıl içinde Teke Mutasarrıfı Cemal Bey'in Dâhiliye Nezareti'ne gönderdiği raporda, Finike isminin değiştirilerek Turan İli yapılmasını önermiş̧ir. Ona göre, uzun zamandır Selçuklu ve Osmanlı egemenliğinde olan Finike'nin, eski Yunanca ismini koruyor olması dikkat çekmekle birlikte, Finike kelimesinin Adana'nın Feke Kazası ve Teke Livası'nın isimleriyle benzerlik gösterdiğinden resmi yazışmalar hep yanlış yerlere gönderilmekte ve bu durum da haberleşme açısından sıkıntıya neden olmaktadır. Söz konusu sıkıntının ortadan kaldırılması için halkı tamamen saf Türklerden oluşan Finike Kazası'nın isminin Turan-ili şeklinde değiştirilmesi liva meclisi tarafından da uygun bulunmuş ve Dâhiliye Nezareti'nin onayına sunulmuştur; ancak bu istek kabul edilmemiştir. ${ }^{86}$

Milli Mücadele Dönemi'nde Ankara Hükümeti'ne ait resmi belgelerde Finike'nin isimlendirilmesinde önemli değişimlerin yaşandığ gözlemlenmektedir. 23 Şubat 1921 tarihli bir belgede Antalya Livası'na bağlı olan ve Finike'nin kuzeydeki dağlık tarafına denk düşen Velikahya Mahallesi'ne Gökbük Köyü adı verilerek, buranın Fenike (ف) ذَ فazası'na bağlanmasıyla ilgili karar alındığı görülmektedir. ${ }^{87}$ Ancak 25 Nisan tarihli, Finike Kazası'na bağlı bir nahiye olan Kumluca'nın merkezi Sarıkavak Köyü'yle ${ }^{88}$ ilgili bir belgede ise Finike bilindik ismiyle geçmektedir. ${ }^{89} 28$ Şubat 1922 tarihli hükümet kararında Fenike'de ticaretle uğraşan, Rodoslu olup aynı zamanda İtalyan pasaportuna sahip olan Osmanlı tebaasından üç Yahudiden bahsedilmektedir. İtalyanlar bu kişilerin Rodos'a gitmelerine izin verilmesini talep etmiştir. Aynı zamanda bu kişiler, Osmanlı tabiiyetini terk etmek istemiştirler. Hükümet ise söz konusu isteği kişilerin bir daha Türkiye'ye gelmemeleri koşuluyla kabul etmiştir. ${ }^{90}$

Öte yandan bu dönem Antalya'daki nüfus kayıtlarında vilayetin iç bölgelerindeki Rumların Türkçe konuştuklarını; ancak içinde Fenike'nin de bulunduğu kıyı yerleşimlerindeki Rumların Yunanca konuştukları ve bunların Tanzimat Fermanı'nın ilanı sonrası Rodos'tan göç edenler oldukları görülmektedir. ${ }^{91}$

\subsubsection{Seyyahların Yerleşime Dair İzlenimleri}

Yakın Çağ'da bölgenin coğrafi ve sosyal durumunu anlatan bir başka belge türü ise 19 . yüzyılda bölgeye uğrayan yabancı seyyahların bölgeyle ilgili izlenimlerini yazdıkları eserlerdir. İlandalı hidrograf ve denizci Francis Beaufort 1811-1812 yıllarında Güney Anadolu kıyılarında yaptığı keşif sonrasında Phineka Vadisi' nin sulak bir yer olduğunu, geçmişte zengin ve gelişmiş birkoloni olabileceğini; ancak içinde bulunduğu dönemde harap bir durumda bulunduğunu

${ }^{85}$ Durgun, agm, s.43; agt, s.74.

${ }^{86}$ Agt, s.74-75.

${ }^{87}$ BCA (Devlet Arşivleri Başkanlığı Cumhuriyet Arşivi), Başbakanlık Kararlar Daire Başkanlı̆̆ , 30.18.1.1/02.36.18, 23.02.1921.

${ }^{88}$ Güçlü, Selçuklulardan, s.238.

${ }^{89}$ BCA, Başbakanlık Kararlar Daire Başkanlı̆̆, 30.18.1.1/117.818.1, 25.04.1921.

90 BCA, Başbakanlık Kararlar Daire Başkanlığ, 30.18.1.1/4.50.17, 28.02.1922; Mustafa Oral, "Duvarlar Arasında Antalya Yahudi Cemaati-II", Tarihin Peşinde-Uluslararası Tarih ve Sosyal Araştırmalar Dergisi, C.3, S.6, 2011, s. 185 .

91 Mehmet Şefik Aker, İstiklâl Harbinde 57. Tümen ve Aydın Millî Cidali: İstiklâl Harbinde Büyük Harbin Mütarekesinden 336 (920) Senesi Sonuna Kadar, C.1, Askeri Matbaa, İstanbul, 1937, s.8. 
söylemiştir. Bununla birlikte, vadinin kumsalında önemli bir çam kerestesi ticareti sürdüğünü de eklemiştir. ${ }^{92}$

Fransız tarihçi, mimar ve arkeolog Félix Marie Charles Texier Anadolu'da bulunduğu 1830 ve 1940'lı yıllarda yaptığı keşif seferleri sırasında Phineka'ya da uğramıştır. Texier izlenimlerini şöyle aktarmaktadır:

"Phineka (Finike) adl, belki de Phoenicus (Fenike) adl gibi Fenikelilerin bu klylda kurdukları kurumların anısinı ifade eden bir kelimedir. Fenikelilerin buralarda ticarethaneleri olduğuna ilişkin kitabelere rastlanır. Doğu klyısındaki Olympus şehrinin de adı Phoenicus idi. Bu adların palmiye ağaçlarından geldiği söylenemez; çünkü bu ağaçların Asya kıyısında hiç fazla şansı olmamış̧ır, bazıları ancak bir rastlantı sonucu yetişmiştir.

Finike köyü Antiphilo'ya benzer. Burada da bir gümrük yeri ile bir kahveci ve bir firın vardır; buna, burada iskele derler. Vapur buradan kereste yükler ve buraya on iki saat mesafede, Likya'nın en büyük kasabası olan Elmalı 'ya gönderilecek, bazı ticari mallar indirir." ${ }^{93}$

Aynı dönem İngiliz arkeolog ve kâşif Charles Fellows da Lykia'da keşif gezisindedir. Fellows, deniz kıyısından iki mil içeride küçük bir köy olan Phineka'nın isminin, Antik Dönem'deki ismi olduğunu düşündüğü Phoenicus'u hatırlattığını söylemiştir. Ona göre, buradaki palmiye ağaçlarından dolayı yerleşime bu isim verilmiş olabilir. Bununla birlikte eğer durum böyle değil ise palmiye ağacı ismini, bu yerleşimden almış olabilir. ${ }^{94}$

Charles Fellows'un ardından bölgede keşif yapan ekibin üyelerinden hidrograf ve jeolog Thomas Abel Brimage Spratt'la doğa tarihçisi Edward Forbes yerleşimle ilgili izlenimlerini ve Phineka'nın İskele olarak isimlendirilişini şu şekilde anlatmıştırlar:

“... koyun kuzeybatı köşesinde sahilde duran çağdaş Finike(Phineka) ${ }^{95}$ kalesiyle karşılaştık. Kuzeydeki surun altından geçip, düzlüğe ulaşır ulaşmaz tam sola çarkettik ve sonra, dă̆ın dibinde, baştan başa açılmış sari süsen (iris) çiçekleriyle saçakll, karanlık ve görünüşte derin bir derenin yanındaki taşlık yolun üstünden karşıya geçtik. Bir mil kadar daha ileride, gün batımından kısa bir süre sonra ulaşmış olduğumuz Finike (Phineka) köyüne geldik. Burada, bizim için şimdi yenilik sayllacak bir yerde - bir Rum meyhanesinde - oda tuttuk...

Finike (Phineka) köyü üç ya da dört taş yapılı evden oluşup, çevresi Türkmen Tahtacıların yaklaşık bir düzine kara çadırıyla kuşatılmıştır. Evlerden birinde gümrük memuru, bir başkasındaysa toprak ve sığır bakımından her ikisinde de varlıkl olmakla ün yapan ve bölgenin belli başlı ticaretini yöneten, Konstanti adında bir Rum oturmaktadır. İçinde yaşadı̆̆ımız kahvehane onun olduğu gibi, buna ekli bir de firın vardır her ikisi de Elmalı'nın bir yerlisi olan ve hem kahvecinin, hem de firıncının görevlerini kendisinde birleştiren ev sahibimiz tarafindan kiralanmıştır...

\footnotetext{
92 Beaufort, age, s.36-37.

${ }^{93}$ Texier, age, s.428.

${ }^{94}$ Charles Fellows, Travels and Researches in Asia Minor: More Particularly in the Province of Lycia, John Murray, London, 1862, s.361.

${ }^{95}$ Eserin Türkçe çevirisinde yerleşim, Finike olarak geçmektedir. Ancak orijinalinde Phineka olduğu için parantez içinde orijinal ismi verilmiştir. Eserin orijinali için bkz. Thomas Abel Brimage Spratt-Edward Forbes, Travels in Lycia, Milyas, and the Cibyratis: In Company with the Late Rev. E. T. Daniell, C.1, John Van Voorst, London, 1847, s.142-146.
} 
Finike (Phineka) Çayı'nın küçük, kara akıntısı, ağır ve durgun sürüklenerek evin önünde yakından geçer ve teknelerin akıntıya karşı neredeyse bir mil kadar daha yukariya gidebilecekleri bir derinliktedir. Tahıl, odun ve benzeri yükler burada doldurup boşaltılarak, çayın ağzına, kalenin bulunduğu ve açığında teknelerin genellikle demir attığı yere getirilir. Bu nedenle, doğru adı Finike (Phineka) olmasına rağmen, köy çoğu zaman İskele diye anılır.

Finike (Phineka), Elmalı'nın ana limanıdır; o kentten sadece on iki ya da on dört saat uzakllkta olup, klş aylarında onun ürünlerine açık olan tek yerdir. Şimdi yük bekleyen bir Rum ıskunası kalenin açığında yatmaktadır, ama bu öteden beri bilinen bir durumdur. Odun ve suyun burada sağlanabilmesindeki kolayllktan ötürü, Konstantinopol ile İskenderiye arasında işleyen Sultanın gemileri tarafindan daha önceleri çok sikllkla uğranılan bir yer olduğu; firının da, onlar için çalışsın diye bir Kaptan Paşa'nın emriyle kurulduğu, bize söylenmişti..."

19. yy'ın son çeyreğinde Fransız coğrafyacı Vital Cuinet, Anadolu'nun sosyo-ekonomik durumunu tespit etmek için yaptığı çalışmada Finika'dan da bahsetmektedir. Deniz kıyısında bir mahalle olarak tanımladığı yerleşimin isminin Phoenicus'tan geldiğini, buranın Fenikeliler tarafından kurulduğu konusunda kuşkusu olmadığını söylemektedir. Üstelik Lykia mezarlarının birisinde erken tarihli bir Fenikece yazı ${ }^{97}$ olduğundan bahsetmektedir. Limanın sık sık rüzgârlara maruz kaldığını; ancak limanın ağzındaki çaydan içeriye doğru kuzeydoğu yönünde gidildiğinde, burada bir deniz barınağı olduğunu ve kış boyunca gemilerin burada tahıl doldurup boşalttığını söylemektedir..$^{98}$

\subsubsection{Nabızade Nazım'ın “Karabibik” İsimli Eserinde Geçen Antik Yerleşimler}

Yazar Nabızade Nazım'ın, Türk Edebiyatı'nın ilk köy romanı olarak bilinen Karabibik isimli romanı 1890 yılında kaleme alınmıştır. Romanda Antalya'nın Kaş ilçesindeki Beymelek Köyü'nde yaşayan Karabibik isimli bir köylünün günlük yaşantısı anlatılmaktadır. Eserde Fenike (Finike)'nin yanı sıra Mira (Myra), Andıraki (Andriake), Pirgos (Pyrgos), Adalya (Antalya), gibi antik yerleşimlerin de ismi geçmektedir. ${ }^{99}$ Karabibik' in Temre (Demre)'den Fenike İskelesi'ne doğru yaptı̆̆ 1 yolculuktan - günümüz Türkçesine çevrilmiş biçimiyle - şöyle bahsedilmektedir:

“Saat biri geçtiği halde Karabibik henüz uyuyamamıştı...

Tam bu esnada denizde, bir mil kadar açıkta Pirgos Kulesi hizasında hareket eden lşıklı bir nokta ortaya çıktı... bu nokta İzmir'le Mersin arasındaki iskelelere çalışmakta bulunan bir vapurun feneriydi... beş buçuk altı mil yol almak üzere yürüyen bu vapur... saat ikide Fenike İskelesi'ne varacaktt." 100

\footnotetext{
${ }^{96}$ Spratt- Forbes, Milyas, s.145.

${ }^{97}$ Limyra'da bulunan bu yazıtla ilgili daha sonra yapılan araştırmalarda, yazıtın Hellenistik Dönem'e ait AramiceGrekçe bilingual bir yazıt olduğu anlaşılmıştır. Bkz. Wörrle, agb, 420.

${ }^{98}$ Vital Cuinet, age, s.865.

99 Eserdeki bilgilerin coğrafi ve arkeolojik verilerle karşılaştırılmasıyla ilgili bkz. G. Gonca Gökalp Alpaslan, “Coğrafyanın ve Arkeolojinin Işı̆̆ında Nabizade Nazım'ın Karabibik Romanı”, Türkbilig, S.13, 2007, s.18-50.

${ }^{100}$ Ed. Şükrü Kanber, Karabibik, Star Medya Yayınları, İstanbul, 2012, s.22.
} 


\subsection{Cumhuriyet Dönemi}

Türkiye Cumhuriyeti'nin kurulmasından sonra 20 Nisan 1924 tarihli Teşkilat-ı Esasiye Капипи gereğince Antalya vilayet olmuş, ${ }^{101}$ Finike kazası da bu vilayete bağlı ilçe statüsünde varlığını devam ettirmiştir. ${ }^{102} 28$ Haziran 1930'da yayımlanan Tütün İnhisarı Kanunu'nda tütün ekiminin yasaklandığ 1 yerlerden biri olarak Finike'nin bulunduğu görülmüş; ancak yerleşimden Fenike olarak söz edilmiştir. ${ }^{103}$ Başka bir resmi kayıtta ise 1935 yılında Fenike'nin Yalnız Köyü’nde valsli ve elektrikli değirmen fabrikası kurulmasına izin verildiği yazılıdır. ${ }^{104}$

1950'lilerde Finike Limanı betonarme bir yapıya büründürülmüştür. ${ }^{105} 1955$ 'te ise iskele bölgesindeki meydanda tamir ve takviye çalışmaları yapılmıştır. Bu çalışmaların yazılı olduğu belgede yerleşimden Fenike iskele meydanı olarak bahsedilmektedir. ${ }^{106}$

1962 yılında Türkiye Cumhuriyeti Hükümeti’nin aldığı kararla turunçgillerin satışıyla ilgili standartlar belirlenmiştir. $\mathrm{Bu}$ standartlara bakıldığında portakal çeşitleri listesinde Finike portakalının da olduğu; ama turunçgil sandıklarının gösterildiği bölümde ise bu portakal çeşidinden Fenike portakalı şeklinde bahsedildiği görülmüştür. ${ }^{107}$ Birinci Beş Yıllık Kalkınma Planı'nın 1963 yılındaki programında ilçedeki hava ve elektrik tesisine ayrlacak bütçe miktarının bulunduğu tabloda, tesisin ismi Fenike olarak gösterilmiştir. ${ }^{108} 1979$ yılında yerleşimde faaliyet gösteren bir narenciye paketleme şirketinin adresinin gösterildiği kayıtta Finike yerine Fenike ibaresi geçmektedir. ${ }^{109}$

1984 yılında yerleşimde seracılık yapan bazı kişilere dair kayıtlarda ilçenin adının Fenike şeklinde yazıldığ 1 görülmüştür. ${ }^{110}$ Hükümet'in 1985 y1lındaki programında, ilçede kurulması hedeflenen sahil sağlık hizmet binasının ismi Fenike'dir. ${ }^{111} 2010$ yılında Yargıtay Başkanlığ 1 tarafından ülkedeki makilerin tanımlanmasıyla ilgili kararda, ilçede yetişen Finike ardıcı, Fenike ardıcı olarak kayda geçmiştir. ${ }^{112}$

\subsubsection{Yerleşimle İlgili Gözlem Yapan Kişilerin Aktardığı Bilgiler}

1925 yılında Ticaret Vekili Ali Cenani Bey, İstanbul'dan Adana'ya doğru yaptığı vapur yolculuğu sırasında uğradığı limanlarla ilgili notlarda, Yunanistan'la yapılan nüfus mübadelesi

101 Feyza Aya, 99 Numaralı Antalya (Finike) Şer'fyye Sicilini’nin Transkripsiyonu ve Değerlendirilmesi H.1335/M.1916 H.1342/M.1924, (Akdeniz Üniversitesi Sosyal Bilimler Enstitüsü, Yayımlanmamış Yüksek Lisans Tezi), Antalya, 2019, s.14.

102 Ertuğrul Kapusuzoğlu, "Bugünkü Finike”, Tarih-Kültür-Folklor-Finike, Ed. Ertuğrul Kapusuzoğlu İstanbul Yayınevi, İstanbul, 2001, s.59.

103 "Tütün İnhisar1 Kanunu”, T.C. Resmi Gazete, 1531/28.06.1930.

${ }^{104}$ BCA, Bakanlıklar Arası Tayin Daire Başkanlığ $, 30.18 .1 .2 / 54.40 .18,22.05 .1935$.

${ }^{105}$ BCA, Bakanlıklar Arası Tayin Daire Başkanlığ , 30.18.1.2/130.75.17, 10.10.1952; Nadir Yurtoğlu, Demokrat Parti Dönemi Tarım Politikaları Ve Siyasi, Sosyal, Ekonomik Hayata Tesirleri (1950-1960), (Hacettepe Üniversitesi Atatürk İlkeleri ve İnkılap Tarihi Enstitüsü, Yayımlanmamış Doktora Tezi), Ankara, 2014, s.204.

106 "Nafia Vekâletinden", T.C. Resmi Gazete, 9037/24.06.1955; 9039/27.06.1955; 9042/30.06.1955.

107 “Turunçgiller Standardı TS/34”, T.C. Resmi Gazete, 11061/20.03.1962; 11062/21.03.1962.

108 "Karar", T.C. Resmi Gazete, 11329/03.02.1963.

109 “Sanayi ve Teknoloji Bakanlığı Teşvik ve Uygulama Genel Müdürlüğü'nce Verilen Teşvik Beldeleri Nisan 1979”, T.C. Resmi Gazete, 16676/24.06.1979.

110 “DPT Teşvik ve Uygulama Başkanlığı'ndan”, T.C. Resmi Gazete, 18461/07.11.1984.

111 “1985 Y1lı Programı Yatırım Projeleri”, T.C. Resmi Gazete, 18628/07.01.1985.

112 “Makilerin Ülkemizde Bulunduğu Alanlar ve Tipleri”, T.C. Resmi Gazete, 27743/28.10.2010. 
sonrasındaki Finike'den de bahsetmiştir. Finike Limanı'nın bölgedeki önemli limanlardan birisi olmakla birlikte, limanın iskelesi olmadığından dolayı derhal bir iskele inşa edilmesi gerektiğini söylemektedir. Bunun yanı sıra, Finike'de yüz elli kadar hane olduğunu ve kasabanın imarı için buraya muhacirlerin getirilip burada oturulmaya mecbur edilmesinin gerektiğini eklemektedir. Ayrıca limanın kaçakçılıkla mücadelesi ve buraya pek çok yelkenlinin uğramasından dolayı, büyük bir önem arz ettiği; yerleşimde daha önce bir Rum tarafindan işletilen otelin, limanın hizmetine verilmesi gerektiğini belirtmiştir. ${ }^{113}$

1926'da İtalyan arkeolog Boggia Pace, bölgede yaptığı gözlemler sonucunda yerleşimin üç gruba ayrıldığını belirtmiştir. İlk grup, deniz kenarındaki resmi yapılar, kışlalar ve evlerden oluşan, Liman, Finike Kalesi veya Finike Limanı olarak isimlendirilen gruptur. İkincisi ise limana bağlı Karaçay üzerinden iç bölgeye doğru, atla on beş dakikalık mesafede bulunan ve yük teknelerinin yanaşabilmesinden dolayı Isskele adı verilen bölgedir. Üçüncüsü de tepeler arasındaki Finike denen büyük merkezdir. ${ }^{114}$

1940'lı yıllarda emekli deniz yarbay Ahmet Rasim'in, Akdeniz kıyılarındaki limanlarla ilgili denizcilere bilgi vermek amacıyla yazdığı eserde Finike Limanı anlatılırken öncelikle Fenikelilere ilişkin tarihi bilgilere yer verilmiştir. Ancak burada Fenikelilerden bahsederken Finikeli ifadesi kullanılmıştır. Daha sonra ise Finike Kasabası'nın ismini Finikelilerden aldığı, burada liman reisliği olduğu, aynı zamanda posta ve telgraf teşkilatı da bulunduğu söylenmektedir. Kasabanın kale civarında olup sahil sıhhiyesinde tabip bulunmadığını belirtilmektedir. Limanda yalnızca küçük sandalların yanaşmasına uygun olan bir iskele olduğu belirtilmekle birlikte; limanın, uygun havalarda gemilerin su ve odun ihtiyacını karşılamaları için en uygun liman olduğu eklenmiştir. ${ }^{115}$

Limyra antik kentinin hafiri Jürgen Borchhardt, 1999 y1lında Limyra'y1 tüm bilimsel yönleriyle anlattığı eserde Finike'yi anlatırken, burada büyük alışveriş pazarları, küçük bir yat limanı, palmiye bahçesi, otel ve pansiyonlar, hastane ve kaymakamlıkla portakal ve limon bahçeleri olduğunu; yerleşimin yaklaşık altı bin kişilik nüfusuyla gelişmekte olduğunu söylemektedir. ${ }^{116}$

\section{Sonuç}

Öncelikle Antik Dönem kaynaklarında Finike'yle ilişkilendiren atıfları tek tek incelemek, ele aldığımız konuların bütününü kavramakta atılacak ilk adımdır. Thukydides'in Phoinike olarak bahsettiği yerin Fenike olması, mantık açısından imkânsızdır. Çünkü Atinalılar, Karia ve Lykia'ya sefer düzenlemektedir. Ayrıca Fenikelilerin korsanlık faaliyetlerinde bulunduğuna dair herhangi bir veri bulunmamaktadır. Üstelik Thukydides Fenike'yi anlatırken başka bir kelime kullanmaktadır. Dolayısıyla sözü edilen yerleşim Lykia'da olmalıdır. Metinde Phoinike'dekilerin korsanlık faaliyetlerinden bahsedilmektedir. Lykia kıyılarında da yüzyıllar

${ }^{113}$ Metnin günümüz Türkçesine transkripsiyonu için bkz. Güçlü, Doğu Akdeniz'de, s.438-439.

114 Boggi Pace'ten aktarım için bkz. Jürgen Borchhardt, “Araştırmaların Tarihçesi”, Ed. Jürgen Borchhardt, Limyra Zemuri Taşları, Çev: Gülay Yümer Arkeoloji ve Sanat Yayınları, İstanbul 1999, s.28.

115 Ahmet Rasim, Akdeniz Kilavuzu-Anadolu, Karaman, Finike ve Kilikya Sahilleri-Mermeris Feneri'nden Payas'a Kadar, TC. Deniz Basımevi, Ankara, 1945, s. 71-72.

116 Borchhardt, $a g b$, s.25. 
boyunca korsanlık faaliyetleri görülmüş olması da Phoinike'nin Lykia'da olduğunu desteklemektedir. Bununla birlikte yerleşimin Finike'yle eşleştirilmesi konusu ise Phaselis'le Phoinike arasındaki bölgeden bahsedilmiş olması nedeniyle mümkün olmakla birlikte; coğrafi olarak Finike'nin Phaselis'ten önce gelmesi nedeniyle bahsedilen yerin daha doğuda olma ihtimali vardir.

Aynı şekilde Plutarkhos'un anlattığı Phoinike'nin de metindeki veriliş sırası dikkate alındığında, Lykia'da olması kuvvetli bir olasılıktır. Ancak Kilikia'nın bölge olması nedeniyle Phoinike'nin de bölge olması muhtemeldir. Dolayısıyla buranın Finike'yle eşleştirilmesinin doğruluk ihtimali azalmaktadır. Üstelik kaynaklarda Geç Antik Çağ'a kadar burayla ilişkilendirilecek herhangi bir atfin bulunmaması da bu ihtimalin azalmasını desteklemektedir. Alexandros'un Lykia kıyılarına uğramadan Ksanthos'tan Phaselis'e geçmiş olması ise sadece bir varsayım olmaktan ibarettir.

Titus Livius'un eserinde Patara'nın iki mil ötesinde olduğunu söylediği Phoenicus Limanı'nın Kemer'de bulunma ihtimali mantıksız olmakla birlikte; Kalkan'da olması mantık çerçevesi içerisinde değerlendirilebilir. Çünkü Patara' yla Kalkan arasındaki deniz mesafesi aşağı yukarı bu miktardır. Üstelik Notitiae Episcopatuum'da Phoinikosluların Patara sakinlerinden sonra görülmüş olması da bu ihtimali güçlendirmektedir. Öte yandan buranın Thukydides'in bahsettiği yerle aynı yer olabileceği görüşü ise yukarıda anlatılan nedenlerden dolayı kabul edilmesi şüpheli bir görüştür. Bununla birlikte Phoinikos'un coğrafi açıdan bakıldığında Finike’yle eşleşme ihtimali de vardır.

Ancak Latince Phoenicus kelimesinin antik Grekçedeki karşıllı̆̆ Phoinikous'tur. Strabon'un anlatıları ve Stadiasmus Maris Magni'de verilen bilgilere bakıldığında Phoinikous'un bir kent olarak MS 3. yy'a kadar bölgeye ismini verdiği; ama bu yüzyıldan itibaren kentin egemenlik alanının küçülmüş olabileceği düşünülebilir. Böylelikle Plutarkhos'un bahsettiği Phoinike'nin kent değil de bölge olması ihtimali daha da kuvvetlenmektedir.

Tüm bu bilgilerden yola çıkarak Phoenicus'la Phoinikous, dilbilimsel açıdan birbirine yakın görünmekle birlikte, coğrafi olarak birbirlerine uzak iki yerleşim olarak görülmektedir. Dolayısıyla bunlar iki farklı yerleşim olabilir. Böylelikle Phoinikos'un Phoenicus'la eşleşmesi ihtimali en aza inmektedir. Buranın Phoinike'yle eşleşmesi de mümkün olabilir. Çünkü yukarıda belirttiğimiz gibi Phoinike'nin kent olmakla birlikte bölge ismi de olma durumu söz konusudur. Öte yandan bahsedilen yer eğer bir kentse, coğrafi olarak Finike'nin doğusunda kaldığından, buranın Finike'yle eşleşmesi söz konusu olamaz.

Sionlu Aziz Nikolaos, bahsettiği iki limandan birisi olan Andriake'nin, Myra'ya ait bir liman olduğu bilinmektedir. Ancak Phoiniks'in lokasyonu ve kime ait olduğu bilinmemektedir. Buranın Limyra'ya ait olduğu önerisi dikkate değer gözükmektedir. Ancak Finike Limanı'nın Limyra'dan bağımsız olduğu görüşünü de dikkate aldığımızda ve Phoiniks'le Finike'yi eşleştirdiğimizde, Phoiniks'in Limyra'ya bağlı olmadığı da düşünülebilir. Üstelik arkeolojik verilere bakıldığında ikisinin arasında bir bağlantı olmadığı da görülmektedir.

Öte yandan Theophanes'le Konstantinos Porphygenitos'un bahsettiği Phoiniks'in hemen hemen aynı yerler olabileceği görülmektedir. Buranın Finike'yle eşleştirilmesi iddiası yukarıdaki 
değerlendirmeler de göz önüne alındığında gayet mantıklıdır. Üstelik Finike'de Osmanlılar zamanında kerestecilik ve gemicilik faaliyetlerini yoğun olduğunun bilinmesi, Theophanes'in bize verdiği bilgileri doğrular niteliktedir. Ancak yine de buranın başka bir yere lokalize edilmesi ihtimali de göz önünde bulundurulmalıdır.

Konularımızın bütününü kavramadaki ikinci adım, Bizans Dönemi’nden günümüze kadar bölgeyle ilgili isimlendirmeler ve bölgenin demografik yapısını incelemektir. 12. yy'da Pisalıların kontrolündeki Finike Körfezi’ndeki limanın ismi olan Phoenix, Grekçedeki Phoiniks kelimesinin Latince karşıllı̆ıdır. Dolayısıyla limanın yukarıda incelediğimiz Phoiniks'le eşleşme ihtimali vardır. Bununla birlikte, limanın bu dönemde kurulmuş olma ihtimali de vardır.

Selçukluların Antalya'yı fethinden sonra Muğla'dan Silifke'ye kadarki kıyı kesiminde zapt ettikleri korsan üslerinin içinde Phoenix de olabilir. Menteşeoğulları Beyliği zamanında bölgenin adının Foke veya Fenike diye isimlendirilmesi ve 13. yüzyılın başında bölgeyle aynı ismi taşıyan bir kentin beyliğin merkezi haline gelmiş olması, Strabon'un bölgeyi isimlendirişini ve Phoinike'nin bölgenin genel adı olduğunu savunan görüşü desteklemektedir. Ayrıca bu durum, Phoinike'nin hem kent hem de bölge olması iddiasıyla da uyumlu görünmektedir.

Aynı yüzyılda bölgenin Teke olarak adlandırıldığına ve bunun nereden kaynaklandığıyla ilgili teorilerin ne olduğuna daha önce yer vermiştik. Bu teorilerin dışında, Teke isminin kökeninin Foke olması ihtimali de ön görülebilir ki, 1914 yılında Teke mutasarrıfının, bölgenin adının Yunanca ismini koruduğunu ve Adana'daki Feke Kazası ve Teke Livası'yla karıştırıldığını söylemesi buna bir gönderme olarak yorumlanabilir. Çünkü Foke'nin yazılışında Arapça $f e$ ve nun harfleri arasında $o$ sesini verecek olan vav harfi bulunmamaktadır. Yani kelimenin Feke olarak okunması ve zamanla Teke'ye dönüşmesi ihtimal dâhilindedir. Üstelik bu isim değişimi, Rumların ve Türklerin yerleşik olarak bir arada yaşadığı dönemde meydana gelmiştir. Böylelikle mevcut teorilere bir yenisi daha eklenmiş olmaktadır.

15. yy'da Finike Limanı'ndan Fenike olarak bahsedilmiştir. Bunun sebebi, yukarıdaki duruma benzer olarak, fe ve nun harflari arasında $i$ sesini verecek olan ye harfinin bulunmayışı olabilir. Ancak bir başka sebep ise liman yerleşimindeki Rum nüfusun çoğunlukta olması ve bundan dolayı limanın ismini koruyor olması ihtimalidir.

16. yy'dan itibaren kayitlarda kentten hem Finike hem de Fenike olarak bahsedilmektedir. Ancak kentin çeşitli mevkileriyle ilgili isimlendirmeler farklılık göstermektedir. Piri Reis Finike Kalesi'nden bahsederken Finike sözcüğünü kullanmış; ancak kentin içindeki köyü Fenike olarak tanımlamıştır. Bu durumun, kalenin Cenevizliler tarafından yapılmış olması ve daha sonra Türklerin eline geçmesi nedeniyle Türklerin bu bölgede yoğun olarak yaşamaları; iç bölgede ise Rum nüfusunun yoğun olmasından kaynaklandığı söylenebilir. Çünkü bir yüzyıl sonra Aziz Stephanos Şovalyeleri Tarikatı'nın kayıtlarında, yerleşime yapılan saldırı sırasında Türklerin topluca intihar ettikleri şeklinde ifadelere rastlanmıştır. Ayrıca yine 16. yy'da dağlık bölgelerde yaşayan yörüklerin Şehr-i Fenike Yörükleri şeklinde anılması da bunu desteklemektedir. 1570'teki Kıbrıs Seferi'nde ise limandan Fenike Limanı olarak bahsedilmiştir.

Öte yandan köye yakın bir mevkide yer alan iskele bölgesi, herhalde görsel benzetmelerden kaynaklansa gerek, Yılanbaşı olarak isimlendirilmiştir. Daha sonraki yüzyıllarda ise bölge Mısır, 
Finike, İskele ve Reşadiye isimlerini almıştır. Benzer şekilde Finike Kalesi de 17. yy'dan itibaren çeşitli isimlere sahip olmuştur. Bunun sebebi, iç kesimlerdeki Rum nüfusunun kültürel olarak Türkleşmesi olabilir. Çünkü 20. yüzyılın başına ait nüfus kayıtlarında Antalya'nın iç kesimlerindeki Rumların Türkçe konuştuğu; içinde Fenike'nin de olduğu kıyı kesimindekilerin ise Yunanca konuştukları görülmektedir. Bunun yanında, 19. yy'da bölgeye uğrayan araştırmacıların anlatıları ve Karabibik isimli eserdeki bilgiler de yukarıdaki durumu destekler niteliktedir.

20. yy'ın başında iç kesimlerin Finike, kıyıların ise Fenike olarak belirtilmesi 16. yy'da başlayan sürecin devamı olarak sayılabilir. Türkiye Cumhuriyeti'nin kurulmasından sonraki nüfus mübadelesinin ertesinde bölgedeki Rumların Yunanistan'a göç ettirilmesiyle birlikte sosyolojik yapı değişmiş ve 1920'lerde kentten Finike olarak bahsedilmiştir. Ancak 1930'lardan günümüze kadar kentten hem Finike hem de Fenike olarak bahsedilmesi, sosyolojik açıdan incelenmeye değer bir konudur.

Konularımızın bütününü anlamamızdaki son adım ise yerleşimin kurucularının kim olduğunun sorgulanmasıdır. Kentin isminin Phoinikous veya Phoinikos'tan gelmiş olduğu iddias1, 19. yy'dan beri dile getirilmektedir. Ancak yukarıda incelediğimiz gibi bu isme sahip yerleşimlerin lokasyonlan tam olarak bilinememektedir. Bununla birlikte kelimenin Phoinike'yle bağlantısından ötürü kentin kurucularının Fenikeliler olduğu iddiası, arkeolojik ve antropolojik temellere dayanmamaktadır.

Öte yandan Limyra'daki kaya mezarındaki Grekçe yazıtta geçen ifadenin henüz başka bir yazıtta görülmemiş olması, yazıttaki kişinin buraya sadece ticari amaçla gelmiş bir Fenikeli olabileceğini göstermektedir. Yani burada kalıcı bir Fenikeli topluluktan söz edilemez. Bunun dışında Çukurova ve çevresinde Fenikelilere ait kalıntılar ve Geç Tunç Çağı'nda Kenanlıların Gelidonya'da ticari faaliyetlerde bulunmaları, onların yalnızca Güney Anadolu kıyılarına daha önceden de bildikleri şeklinde yorumlanabilir.

Kentin adının Phoinikos'tan geldiğini iddia eden görüş ise bu kelimenin kızıl renkli at veya kızıl renkli davar sürüsü anlamı taşıdığını belirtmektedir. Ancak Phoiniks kelimesinin tanımlamasında böyle bir anlam bulunmamaktadır. Dolayısıyla bu ve yerleşimdeki en erken buluntuların Hellenistik Dönem'e ait olmasından dolayı yerleşimin kurucularının Grekler olduğunu söylemek, pek sağlık bir yorum gibi gözükmemektedir.

19. yy gezginlerinden birisinin Phoinikous'la ilgili yaptığı yorumlar ise oldukça ilginçtir. Yorumda Phoinike'nin anlamları içerisinde yer alan palmiye ağacının yerleşimde görülmesinden dolayı yerleşimin bu ismi almış olabileceği ihtimali, aynı dönem Fenike'yle ilgili yapılan çalışmada, Phoinike isminin palmiye ağacından geldiği yorumuyla örtüşmektedir. Ancak daha sonra bunun böyle olmadığı ortaya çıkmıştır. Üstelik aynı dönem buraya uğrayan başka bir gezgin ise palmiye ağacının Asya kıyılarında yetişmesinin pek mümkün olmayacağını söyleyerek bu teze karşı çıkmıştır. Gezginin yorumundaki bir diğer ihtimal ise palmiye ağacının ismini, bu yerleşimden alıyor olmasıdır ki, eğer böyle bir ihtimal gerçekse Erythrai, Messenia, Kythera, Marmarika ve Girit’te aynı isme sahip liman yerleşimleri için de başka bir tartışma konusu ortaya çıkacaktır. 
Sonuç olarak Phoinike (Fenike) ve varyasyonlarının bölgenin genel ismi olma ihtimali kuvvetli gözükmektedir. Zaman içerisinde Finike'nin iç ve kıyı kesimleri arasındaki isimlendirme farklılıklarının ortaya çıkmasında, bölgenin kültürel anlamda Türkleşme sürecinin önemli bir etkisi olduğu düşünülebilir. Yerleşimin ilk kurucularının kim olduğu ve Fenike isminin hala daha neden kullanıldığı konularıyla ilgili tarih ve arkeoloji bilimlerine ait mevcut veriler, bu konuların tespiti için yeterli gözükmemektedir. Bu durumda sosyoloji, antropoloji ve hatta pozitif bilim alanlarında yapılacak olan çalışmaların, konuların netleşmesine büyük katkı sunacağı ön görülmektedir.

\section{Kaynakça}

\section{Antik Kaynaklar}

Konstatinos Porphygenitos, De thematibus et de administrando imperio, Ed. Immanuel Bekkerus, Ed. Weberi, Bonnae, 1840.

Stadiasmus Maris Magni, Nihal Tüner, Lykia'nın Yerleşim Coğrafyasında Yeni Lokalizasyonlar, (Akdeniz Üniversitesi Sosyal Bilimler Enstitüsü, Yayımlanmamış Doktora Tezi), Antalya, 2002, s.145

Strabon, Antik Anadolu Coğrafyası (Geographika: XII-XIII-XIV), Çev: Adnan Pekman, Arkeoloji ve Sanat Yayınları, 2001.

Theophanes, The Chronicle Of Theophanes, Çev: Harry Turtledove, University of Pennysylvania Press, Philadelphia, 1982.

Thukydides, Peloponnesos Savaşları, Çev: Furkan Akderin, Belge Yayınları, İstanbul, 2007.

Titus Livius, History of Rome, Volume XI, Books 38-39, Çev: Evan T. Sage, Harvard University Press, Cambridge, Massachusets, 1936.

Vita Nicolai Sionitae, Ceren Pilevneli, M.S. IV.-VII. Yüzyıllarda Myra (Lykia) ve Egemenlik Alanında Hristiyanlı, (Marmara Üniversitesi Türkiyat Araştırmaları Enstitüsü, Yayımlanmamış Yüksek Lisans Tezi), İstanbul, 2013, s.64-65.

\section{Arşiv Belgeleri}

\section{Devlet Arşivleri Başkanlığı Osmanlı Arşivi}

BOA. A. DVNSMHM.d..., 127/1290-1307, (H.1131.S.10).

BOA. C. ZB, 47/2341, (H.1173.Zk.15).

\section{Devlet Arşivleri Başkanlığı Cumhuriyet Arşivi}

BCA, Bakanlıklar Arası Tayin Daire Başkanlığı, 30.18.1.2/54.40.18, 22.05.1935.

BCA, Bakanlıklar Arası Tayin Daire Başkanlığı, 30.18.1.2/130.75.17, 10.10.1952

BCA, Başbakanlık Kararlar Daire Başkanlığı, 30.18.1.1/02.36.18, 23.02.1921.

BCA, Başbakanlık Kararlar Daire Başkanlığı, 30.18.1.1/117.818.1, 25.04.1921.

BCA, Başbakanlık Kararlar Daire Başkanlığı, 30.18.1.1/4.50.17, 28.02.1922. 


\section{T.C. Resmi Gazete}

“1985 Y11 Programı Yatırım Projeleri”, 18628/07.01.1985.

“DPT Teşvik ve Uygulama Başkanlığı'ndan”, 18461/07.11.1984.

“Karar”, 11329/03.02.1963.

“Makilerin Ülkemizde Bulunduğu Alanlar ve Tipleri”, 27743/28.10.2010.

“Nafia Vekâletinden”, 9037/24.06.1955. , 9039/27.06.1955. 9042/30.06.1955.

“Sanayi ve Teknoloji Bakanlığı Teşvik ve Uygulama Genel Müdürlüğü’nce Verilen Teşvik Beldeleri Nisan - 1979", 16676/24.06.1979.

“Turunçgiller Standardı TS/34”, 11061/20.03.1962. $11062 / 21.03 .1962$.

“Tütün İnhisarı Kanunu”, 1531/28.06.1930.

\section{Epigrafik Kaynaklar}

Ed. Ernst Kalinka, Tituli Asiae Minoris. Vol. 1, Tituli Lyciae lingua Lycia conscripti, Alfredi Hoelderi, Vindobonae, 1901.

ŞAHIN, Sencer-Mustafa Adak, Stadiasmus Patarensis: Itinera Romana Provinciae Lyciae, Ege Yayınları, İstanbul, 2007.

\section{Modern Kaynaklar}

ACIPINAR, Mikail, “Güney Anadolu Kıyılarında Hristiyan Korsanlar (1604-1608)”, Akademik Bakış, C.11, S.21, 2017, s.183-208.

ADAK, Mustafa, "Lokalisierung von Olympos und Korykos in Ostlykien”, Gephyra, C.1, 2004, s.27-51.

AKER, Mehmet Şefik, İstiklâl Harbinde 57. Tümen ve Aydın Millî Cidali: İstiklâl Harbinde Büyük Harbin Mütarekesinden 336 (920) Senesi Sonuna Kadar, C.1, Askeri Matbaa, İstanbul, 1937.

AKBAL, Fazıla, “1831 Tarihinde Osmanlı İmparatorluğu'nda İdari Taksimat ve Nüfus”, Belleten C.15, S.60, 1951, s.617-628.

ALPASLAN, G. Gonca Gökalp, “Coğrafyanın ve Arkeolojinin Işı̆̆ında Nabizade Nazım'ın Karabibik Romanı”, Türkbilig, S.13, 2007, s.18-50.

Antiquities of Ionia, C.3, The Society of Dilettanti, London 1840.

AUBET, Maria Eugenia, The Phoenicians and the West: Politics, Colonies and Trade, Cambridge University Press, Cambridge, 1993. 
BASS, George F.-Peter Throckmorton,-Joan Du Plat Taylor-J. B. Hennessy-Alan R. ShulmanHans-Günter Buchholz, "Cape Gelidonya: A Bronze Age Shipwreck", Transactions of the American Philosophical Society, New Series, C.57, S.8, s.1-177.

BAYBURTLUOĞLU, Cevdet, "Finike İlçesi ve İlçe Sınırları İçinde Kalan Kalıntılar", TarihKültür-Folklor-Finike, Ed. Ertuğrul Kapusuzoğlu, İstanbul Yayınevi, İstanbul, 2001, s.2730.

BEAUFORT. Francis, Karamania: Or, A Brief Description of the South Coast of Asia-Minor and of the Remains of Antiquity. With Plans, Views, \&c. Collected During a Survey of that Coast, Under the Orders of the Lords Commissioners of the Admiralty, in the Years 18111812, R. Hunter, London 1817.

BOSWORTH, Albert Brian, Conquest and Empire: The reign of Alexander the Great, Cambridge University Press, New York 2009.

BORCHHARDT, Jürgen, “Araştırmaların Tarihçesi”, Ed. Jürgen Borchhardt, Limyra Zemuri Taşları, Çev: Gülay Yümer Arkeoloji ve Sanat Yayınları, İstanbul 1999, s.25-30.

BRYCE, Trevor, The Lycians in Literary and Epigraphic Sources, C.1, Museum Tusculanum Press, Copenhagen, 1986.

BUSCHMANN, K., "Die Expedition des Melesander nach Lykien 430/29 v.Chr. und die

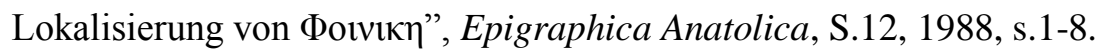

CRAWLEY, Richard, The History Of Peloponnesian War by Thucydides, E. P. Dutton Company and Inc.-J. M. Dent and Sons Limited, New York-London, 1950.

CUINET, Vital, La Turquie d'asie Géographie Administrative Statistique Descriptive et Raisonnée de Chaque Province de l'asie Mineure. C.1, Ernest Leroux, Paris, 1892.

ÇEVIK, Nevzat, "Rhodiapolis ve Kumluca Sınırları İçindeki Diğer Antik Yerleşimler", Arkeolojisi, Tarihi, Doğası ve Tarımıla Kumluca - Rhodiapolis, Ed. Nevzat Çevik, Kumluca Belediyesi Yayınlar1, Antalya, 2008, s.1-75.

ÇEVIK, Nevzat, Süleyman Bulut, Çakır Afşin Aygün, "Myra'nın Limanı Andriake”, Byzas,C.1 S.19, 2014, s.225-243.

DEMİR, Mahmut, “Antalya'nın Türkiye Selçukluları Tarafından Fethi”, Cedrus, S.7, 2018, s.555-571.

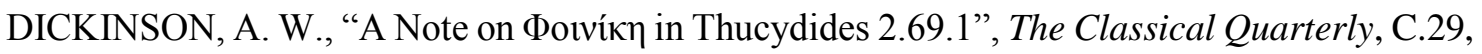
S.1, 1979, s.213-214.

DONNEGAN, James, A New Greek and English Lexicon; Principally on the Plan of the Greek and German Lexicon of Schneider: the Words Alphabetically Arranged; Distinguishing such as Are Poetical, of Dialectic Variety, or Peculiar to Certain Writers and Classes of Writers; with Examples, Literally Translated, Selected from the Classical Writers, Hilliard, Gray \& Co.-G. \& C. Carvill \& Co, Boston-New York, 1840. 
DUGGAN, T. Mikail P.-Çakır Afşin Aygün, "The Medieval and Later Port of Myra/Stamira Taşdibi”, Byzas, C.1, S.19, 2014, s.245-269.

DURGUN, Hatice, “XIX. Yüzyılda Finike'nin İdari ve Sosyo-Ekonomik Yapısından Kesitler”, Akademik Incelemeler Dergisi, C.12, S.2, 2017, s.35-63.

FELLOWS, Charles, Travels and Researches in Asia Minor: More Particularly in the Province of Lycia, John Murray, London, 1862.

ED. Hubert Cancik-Helmuth Schneider, Brill's New Pauly : Encyclopaedia of the Ancient World: Antiquity, C.11, Brill, Leiden-Boston, 2007.

ED. Jürgen Borchhardt, Limyra Zemuri Taşları, Çev: Gülay Yümer Arkeoloji ve Sanat Yayınları, İstanbul, 1999.

ED. Seyit Ali Kahraman, Günümüz Türkçesiyle Evliyâ Çelebi Seyahatnamesi: Kütahya, Manisa, İzmir, Antalya, Karaman, Adana, Halep, Şam, Kudiis, Mekke, Medine, C.9, K.1, Yap1 Kredi Yayınları, İstanbul, 2011.

ED. Şükrü Kanber, Karabibik, Star Medya Yayınları, İstanbul, 2012.

ED. Yavuz Senemoğlu, Kitab’ı Bahriyye: Denizcilik Kitabı, C.2, Tercüman Gazetesi Yayınları, İstanbul, 1973.

ELAYI, Josette, The History of Phoenicia, Lockwood Press, Atlanta, 2018.

ERDEM, İlhan, "Ortaçağ Sonlarında Likya Levant Ticareti ve Türkmenler (12.-15. YY.)", III. Likya Sempozyumu 7-10 Kasım 2005, Sempozyum Bildirileri, C.I, İstanbul, 2006, Ed. Kayhan Dörtlük, Tarkan Kahya, Burhan Varkıvanç, Suna-İnan Kıraç Akdeniz Medeniyetleri Araştırma Enstitüsü, Antalya, 2006, s.243-251.

"Bir Ortaçağ Kenti Antalya: Geç Antik Dönemden Selçukluların Sonuna Genel Bir Yaklaşım (II)", Adalya, S.6, 2003, s.293-304.

FLEMING, Walter Bruce, The History of Tyre, Columbia University Press, New York, 1915.

GREEN, Peter, Alexander of Macedon 356-323 B.C.: A Historical Biography, University of California Press, Berkeley, Los Angeles, London 2013.

GÜÇLÜ, Muhammet, "Selçuklulardan Cumhuriyet'e Kumluca (Antalya) Bölgesi”, Türkiyat Araştırmaları Dergisi, S.22, 2007, s.219-250.

"Doğu Akdeniz'de Bir Liman Kenti: Finike", Osmanlı Dönemi Akdeniz Dünyası, Ed. Haydar Çoruh-M. Yaşar Ertaş-M. Ziya Köse, Yeditepe Yayınları, İstanbul, 2011, s.415-441.

HAMMOND, Martin, Thucydides: The Peloponnesian War, Oxford University Press, New York, 2009.

HOBBES, Thomas, The History of the Grecian War Written by Thucydides, John Bohn, London, 1843.

HORNBLOWER, Simon, A Commentary on Thucydides, C.1, Clarendon Press, Oxford 2003. 
JOWETT, Benjamin, Thucydides translated into English; with introduction, marginal analysis, notes, and indices, C.1, Clarendon Press, Oxford, 1881

KAPUSUZOĞLU, Ertuğrul, "Bugünkü Finike”, Tarih-Kültür-Folklor-Finike, Ed. Ertuğrul Kapusuzoğlu İstanbul Yayınevi, İstanbul, 2001, s.59.

, “İlk Finike’nin Yeri”, Tarih-Kültür-Folklor-Finike, Ed. Ertuğrul Kapusuzoğlu İstanbul Yayınevi, İstanbul, 2001, s.1.

KEEN, Antony G., Dynastic Lycia: A Political History of the Lycians and their Relations with foreign Powers, c. 545-362 B.C., Brill, Leiden, Boston, Köln 1998.

KRICKL, Ernest, 1892 Lykia Günlüğ̈̈, Çev: Z. Zühre İlkgelen, Suna ve İnan Kıraç Vakfı Yayınları-Arkeoloji ve Sanat Yayınları, İstanbul, 2005.

LE ROY, Christian, "Alexandre À Xanthos", Actes du Colloque sur la Lycie antique, Libr. d'Amérique et d'Orient Adrien Maisonneuve, Paris 1980, s.51-61.

LEAKE, William Martin, Journal of a Tour in Asia Minor,: With Comparative Remarks on the Ancient and Modern Geography of that Country, John Murray, London, 1824.

LEHMANN, Gunnar, "North Syria and Cilicia, c. 1200-330 BCE", Beyond the Homeland: Markers in Phoenician Chronology, Ed. Claudia Sagona. Peeters, Paris, 2008, s.205-246.

LEMPRIÉRE, John, A Classical Dictionary: Containing A Copious Account of All the Proper Names Mentioned in Ancient Authors; with the Value of Coins, Weights, And Measures, Used among the Greeks and Romans; and a Chronological Table, T.Caddell, London, 1823.

MOSCATI, Sabatino, Fenikeliler, Çev: Sinem Gül, Dost Kitabevi, 2004.

ORAL, Mustafa, "Duvarlar Arasında Antalya Yahudi Cemaati-II", Tarihin Peşinde-Uluslararası Tarih ve Sosyal Araştırmalar Dergisi, C.3, S.6, 2011, s.177-194.

PAUWELS, Jacques R., Beneath the Dust of Time: A History of the Names of Peoples and Places, Bat

PETERSEN, Eugen Adolf Hermann-Felix von Luschan, Reisen in Lykien, Milyas und Kibyratis, Gerold, Wien, 1889, tle Bridge Publications, London-Colombo, 2009.

Piri Reis, Kitāb-i Baḩriye (Book on Navigation), The Walters Art Museum, Baltimore, 2011

RASIM, Ahmet, Akdeniz Kilavuzu-Anadolu, Karaman, Finike ve Kilikya Sahilleri-Mermeris Feneri'nden Payas'a Kadar, TC. Deniz Basımevi, Ankara, 1945.

RAWLINSON, George, History of Phoenicia, Longmans, Green, and Co, London-New York, 1889

RUGE, Walther, "Phoinix 15", Realencyclopädie der classischen Altertumswissenschaft, C.20 K.1, Metzler, Ed. Karl Mittelhaus, Stuttgart, 1943, s.428-431.

SMITH, William, Dictionary of Greek and Roman Geography, C.2, Little, Brown, Company, Boston, 1857.

History Studies 
SPRATT, Thomas Abel Brimage-Edward Forbes, Milyas, Kibyratis ve Likya'da Yolculuklar, C.1, Çev: Doğan Türker, Suna - İnan Kıraç Akdeniz Medeniyetleri Araştırma Enstitüsü, Antalya, 2008.

Travels in Lycia, Milyas, and the Cibyratis:

In Company with the Late Rev. E. T. Daniell, C.1, John Van Voorst, London, 1847

STARK, Freya, “Alexander's March from Miletus to Phrygia”, The Journal of Hellenic Studies, C.78, 1958, s.102-120.

ŞAHIN, Sencer, "Stadiasmus Patarensis: Likya'nın Roma Yolları", Arkeoloji ve Sanat Dergisi, S.136, 2011, s.98-103. "Pamfilya/Likya Sınır Kentleri: Olbia ve Diğerleri”, Likya İncelemeleri, C.1, Ed. Sencer Şahin-Mustafa Adak, Arkeoloji ve Sanat Yayınları, İstanbul, 2002, s.9-41.

TEXIER, Félix Marie Charles, Küçük Asya Coğrafyası, Tarihi ve Arkeolojisi, C.3, Çev: Ali Suat, Enformasyon ve Dökümantasyon Hizmetleri Vakfı Yayınları, Ankara 2002.

THUKYDIDES, Peloponnesos Savaşları, Çev: Furkan Akderin, Belge Yayınları, İstanbul, 2007.

UĞURLU, Elif, “Olympos ve Zeniketes'in Kalesinin Lokalizasyonu”, Adalya, S.10, 2007, s.123.

UZUNÇARŞILI, İsmail Hakkı, Anadolu Beylikleri ve Akkoyunlu, Karakoyunlu Devletleri, C.1, Türk Tarih Kurumu Basımevi, Ankara, 2003.

, Osmanlı Tarihi, C.1-3, Türk Tarih Kurumu Basımevi, Ankara, 1988.

WITTEK, Paul, Menteşe Beylı̆̆̂̀: 13-15 İnci Asırda Garbî Küçük Asya Tarihine Ait Tetkik, Çev: Orhan Şaik Gökyay, Türk Tarih Kurumu Basımevi, Ankara, 1944.

WORRLE, Michael, "Die griechischen Sepulkralinschriften von Limyra", Limyra: Studien zu Kunst und Epigraphik in den Nekropolen der Antike, Ed. Jürgen Borchhardt-Anastasia Pekridou-Gorecki, Phoibos Verlag, Wien, 2012, s.411-474.

YÜCEL, Yaşar, XIII-XIV. Yüzyıllarda Kuzey-Batı Anadolu Tarihi-Çoban-Oğulları, CandarOğulları Beylikleri, Türk Tarih Kurumu Basımevi, Ankara, 1980.

ZIMMERMANN, M., "Noch einmal Thuk. II 69 und ФOINIKH”, Hermes, S.121, 1993, s. 266275.

\section{Tezler}

ARMAĞAN, Abdüllatif, XVI. Yüzyılda Teke Sancă̆ı (Tapu-Tahrir Defterlerine Göre), (Ankara Üniversitesi Sosyal Bilimler Enstitüsü, Yayımlanmamış Doktora Tezi), Ankara, 1996.

AYA, Feyza, 99 Numarall Antalya (Finike) Şer'Iyye Sicilini’nin Transkripsiyonu ve Değerlendirilmesi H.1335/M.1916 H.1342/M.1924, (Akdeniz Üniversitesi Sosyal Bilimler Enstitüsü, Yayımlanmamış Yüksek Lisans Tezi), Antalya, 2019 
DURGUN, Hatice, XIX. Yüzyılda Teke Sancağı'na Bă̆lı Elmalı Kazası'nın Sosyo-Ekonomik Yapısı (1839-1914), (Akdeniz Üniversitesi Sosyal Bilimler Enstitüsü, Yayımlanmamış Doktora Tezi), Antalya, 2014.

KARACA, Behset, XV ve XVI. Yüzyıllarda Teke Sancağl, (Ondokuz Mayıs Üniversitesi Sosyal Bilimler Enstitüsü, Yayımlanmamış Doktora Tezi), Samsun, 1997.

KUBAY, Zeynep, Die Felsgraber vol Limyra in Lykien (Likya'da Limyra Kaya Mezarları), (İstanbul Teknik Üniversitesi Fen Bilimleri Enstitüsü, Yayımlanmamış Doktora Tezi), İstanbul, 1996.

SARI, Serkan, XV-XVI. Yüzyıllarda Menteşe, Hamid ve Teke Sancağı Yörükleri, (Süleyman Demirel Üniversitesi Sosyal Bilimler Enstitüsü, Yayımlanmamış Doktora Tezi), Isparta, 2008.

YURTOĞLU, Nadir, Demokrat Parti Dönemi Tarım Politikaları Ve Siyasi, Sosyal, Ekonomik Hayata Tesirleri (1950-1960), (Hacettepe Üniversitesi Atatürk İlkeleri ve İnkılap Tarihi Enstitüsü, Yayımlanmamış Doktora Tezi), Ankara, 2014.

\section{İnternet Kaynakları}

İskele Mahallesi'nin Uydudan Görünümü https://earth.google.com/web/@36.31388595,30.13583191,4.13868959a,1007.37310005 d,35y,0h,0t,0r (E.T. 10.07.2020).

Volume 12

ÖZTÜRK, Murat, "Zâtüssavârî", TDV İslâm Ansiklopedisi, TDV İslâm Araştırmaları Merkezi, 2013, https://islamansiklopedisi.org.tr/zatussavari (E.T. 10.07.2020) 


\section{HARITALAR}

Harita 1: Finike ve çevresi (Kapusuzoğlu, İlk Finike'nin, s.1).

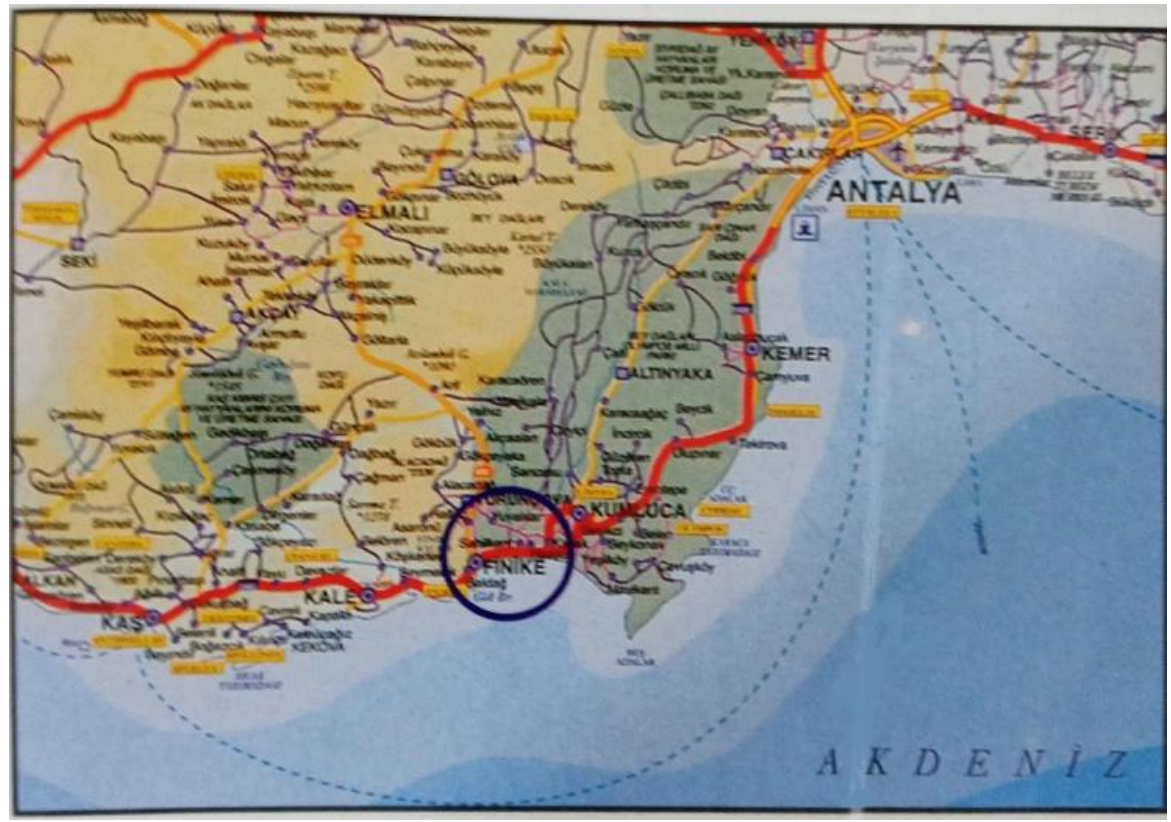

Harita 2: Stadiasmus Patarensis’teki Myra-Limyra Güzergâhı (Şahin-Adak, age, s.263).

Volume 12

Issue 5

October

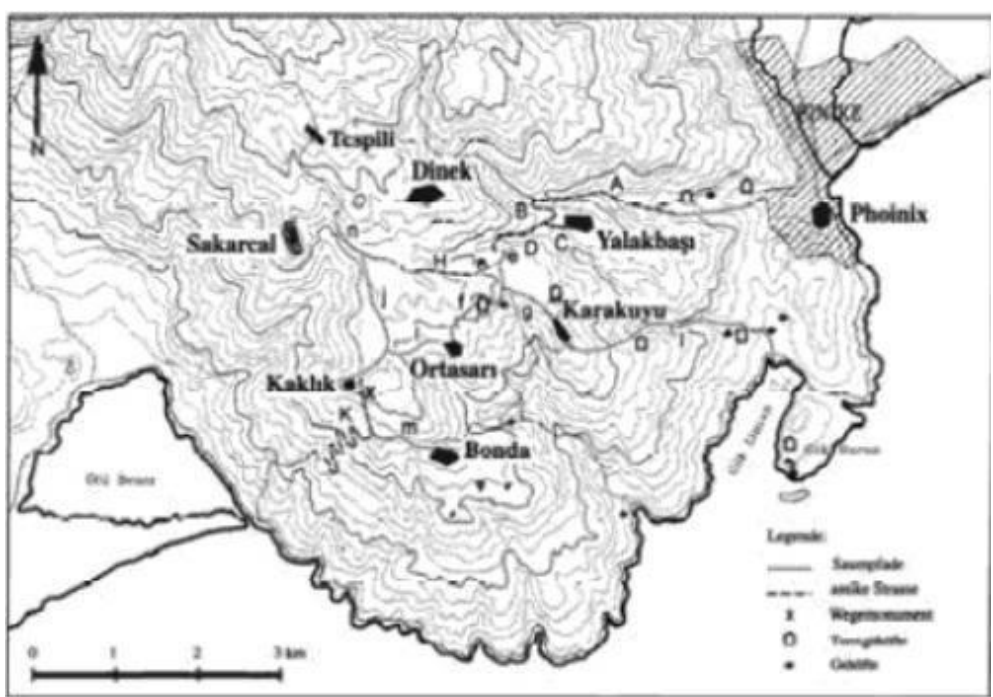

2020 
Harita 3: Kitab- Bahriyye'de Finike ve çevresindeki limanlar (Ed. Yavuz Senemoğlu, age, s.287).

\section{颣 $\frac{\text { HISTORY }}{\text { STUDIES }}$ 2345 \\ Volume 12 \\ Issue 5 \\ October 2020}

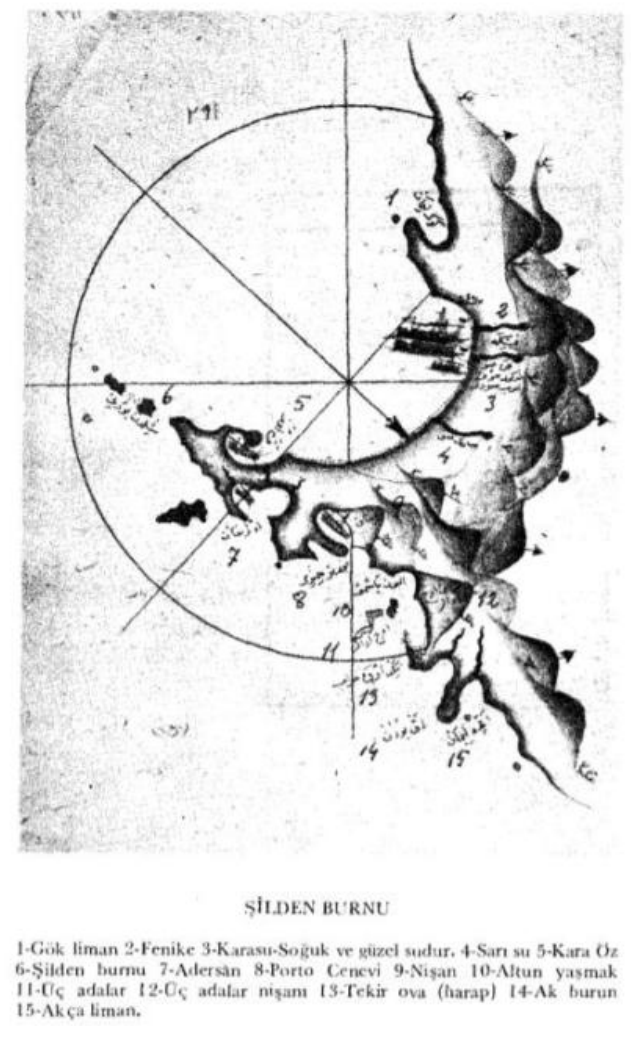

Harita 4: İskele Mahallesi'nin uydudan görünümü (https://earth.google.com/web/@36.31388595,30.13583191,4.13868959a,1007.37310005d,35y,0h,0t,0r)

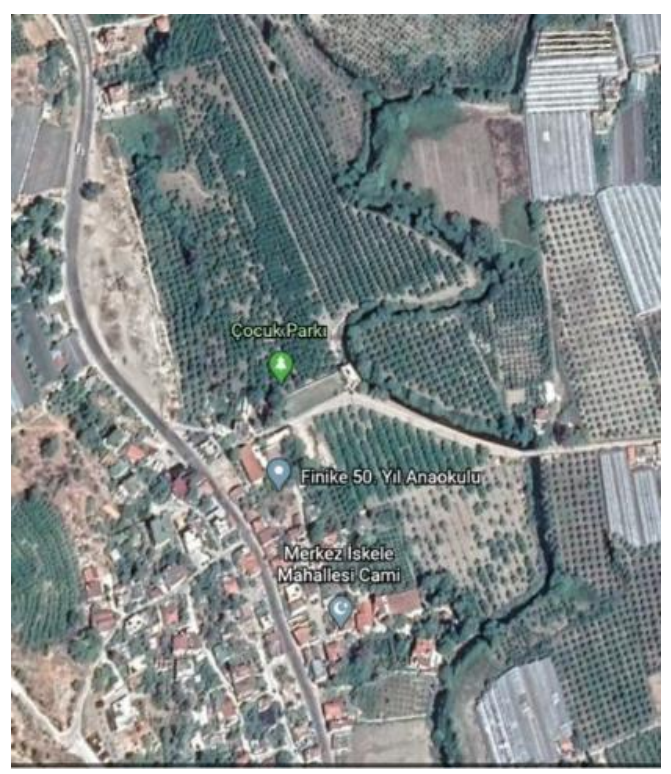


Finike-Fenike Eşleşmesinin Kökenleri ve “Finike” İsminin Günümüze Ulaşması

\section{RESIMLER}

Resim 1: Aziz Stephanos Şovalyeleri'nin Finike Kalesi'ne saldırmalarının tasvir edildiği minyatür (Acıpınar, agm, s.208, ş.3).

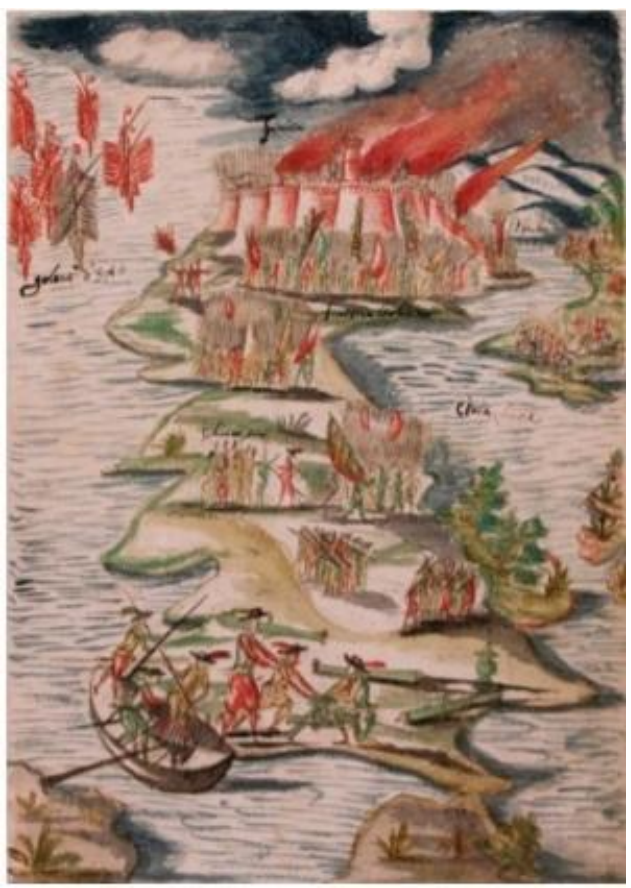

Volume 12

Issue 5

October

2020 